NBER WORKING PAPER SERIES

\title{
DOES THE IMPACT OF MANAGED CARE ON SUBSTANCE ABUSE TREATMENT SERVICES VARY BY PROFIT STATUS?
}

\author{
Jody Sindelar \\ Todd Olmstead \\ Working Paper 10745 \\ http://www.nber.org/papers/w10745
NATIONAL BUREAU OF ECONOMIC RESEARCH
1050 Massachusetts Avenue
Cambridge, MA 02138
September 2004

We acknowledge financial support from the National Institute on Drug Abuse (NIDA RO1-DA14471). The views expressed herein are those of the author(s) and not necessarily those of the National Bureau of Economic Research.

(C)2004 by Jody Sindelar and Todd Olmstead. All rights reserved. Short sections of text, not to exceed two paragraphs, may be quoted without explicit permission provided that full credit, including $\odot$ notice, is given to the source. 
Does the Impact of Managed Care on Substance Abuse Treatment Services Vary By Profit Status? Jody Sindelar and Todd Olmstead

NBER Working Paper No. 10745

September 2004

JEL No. I1

\begin{abstract}
$\underline{\text { ABSTRACT }}$
We extend our previous research by determining whether, and how, the impact of managed care on substance abuse treatment (SAT) services differs by facility ownership.

We use the 2000 National Survey of Substance Abuse Treatment Services that contains data on service offerings and other characteristics of 10,513 SAT facilities. For each group of for-profit, notfor-profit, and public facilities, we estimate the impact of managed care (MC) on the number and types of SAT services offered (i.e., indicators of the quality of care). We use IVs to account for possible endogeneity between facilities' involvement in MC and service offerings.
\end{abstract}

We find substantial differences in the magnitude and direction of the impact of MC by facility ownership. On average, MC causes for-profits to offer approximately four (out of 26) additional services, causes publics to offer approximately four fewer services, and has no impact on the number of services offered by not-for-profits.

Our findings raise concerns that managed care may reduce the quality of care provided by public SAT facilities by limiting the range of services offered. On the other hand, for-profit clinics are found to increase their range of services; the societal impact of this is unclear for several reasons.

Jody Sindelar

Yale School of Public Health

Yale University School of Medicine

60 College Street

PO Box 208034

New Haven, CT 06520-8034

and NBER

jody.sindelar@yale.edu
Todd Olmstead

Yale School of Public Health

Yale University School of Medicine

60 College Street

PO Box 208034

New Haven, CT 06520-8034

todd.olmstead@yale.edu 


\section{INTRODUCTION}

This paper extends our previous research by determining whether, and how, the impact of managed care on service offerings varies by the profit status of the substance abuse treatment facility. It adds to the literature on the impact of profit status on the provision of health care and extends this literature to the relatively less studied area of substance abuse treatment. This topic is important for several reasons. Substance abuse is an important and costly problem, harming abusers as well as their families, friends, and society (ONDCP 2001, Harwood, Fountain and Livermore 1998). Effective treatment can reduce many of these costs (IOM 1990, ONDCP 1996, National Consensus Development Panel on Effective Medical Treatment of Opiate Addition 1998, NIDA 1999). In addition, managed care (MC) has been growing rapidly in the substance abuse treatment (SAT) field, and there is some concern that MC's emphasis on costcontainment may result in fewer services offered, thus reducing treatment effectiveness (Olmstead, White and Sindelar 2004, Alexander, Lemak and Campbell 2003). Reduced effectiveness, in turn, could have a negative impact on society through increases in crime, welfare dependency, and spread of infectious diseases.

Substance abuse treatment is provided by a mix of for-profit (FP), not-for-profit (NFP), and public providers. The majority of the providers in the SAT market are NFPs and the fewest number are publics. However, publics tend to be larger in terms of people treated per clinic. Characteristics of SAT facilities vary systematically by ownership type for several reasons, including differences in mission, client mix, and opportunities and constraints imposed by their profit status. For-profits, for example, tend to serve clients who have relatively fewer comorbidities and are privately insured or able to pay for care out-of-pocket, while publics tend to treat clients who have relatively more comorbidities and whose care is supported by 
government financing (Rodgers and Barnett 2000, Wheeler and Nahra 2000, Ettner et al. 2003).

These differences suggest that the impact of managed care may vary by profit status.

This paper focuses on how managed care differentially affects the range of services offered by providers with different ownership types. Range of services is a key measure of treatment effectiveness (Olmstead, White and Sindelar 2004). Treatment effectiveness is improved by the availability of a range of services, including social and medical services, necessary to meet the wide spectrum of needs faced by drug-dependent individuals (McLellan et al. 1993, Milby et al. 1996, McLellan et al. 1998, McLellan et al. 1999, Gould, Levine and McLellan 2000, Marsh, D'Aunno and Smith 2000, Smith and Marsh 2002). While there is a growing interest in the effects of MC on SAT generally, relatively few studies have focused on the effects of MC on the number and type of SAT services offered, and none of these examine whether and by how much the effect varies by the ownership type of the provider.

This study presents empirical evidence on these issues. Data from more than 10,000 SAT facilities in the US are used in these analyses. We use the instrumental variables approach to identify the effects of MC on SAT service offerings, thus going beyond pure association, as is common in this literature, to causal effects. We examine the offerings of twenty-six different services. Because our data comprise virtually the universe of SAT facilities, our statistical power is high and our results are nationally generalizable. Our findings should be of interest to policy makers, researchers, patients, public and private payers, clinics and clinicians.

\section{RELEVANT SAT LITERATURE}

A substantial body of literature addresses differences across firms by profit status generally (Hansman 1980, Weisbrod 1988, Kapur and Weisbrod 2002, and for a summary see Steinberg 2004). The health care delivery system, in particular, is characterized by a mix of 
NFPs, FPs, and publics in a market. With this interesting mix of ownership types, there have been substantial analyses of differences by profit status for various types of health care markets, e.g. hospitals (see Newhouse 1970 for a classic), nursing homes (Hirth 1999), and hospice (Lindrooth and Weisbrod 2004, Carlson, Gallo and Bradley 2004). However, there has been relatively less analysis of the impact of profit status in the SAT delivery system. We discuss first literature on facility ownership in the SAT market and then briefly review literature on MC in SAT.

Facility ownership

Research has shown that the profit status of SAT facilities is associated with differences in clientele, access to care, and services offered. Considerable research has shown evidence of a two-tiered substance abuse treatment system in which FPs cater to and serve clients that are typically privately insured (or able to pay for care out-of-pocket) and have relatively fewer comorbidities, while publics tend to treat clients whose care is supported by government financing and who have relatively more comorbidities (Rodgers and Barnett 2000, Wheeler and Nahra 2000, Ettner et al. 2003).

The relationship between facility ownership and the SAT delivery system has been examined in a number of studies. Friedmann et al. (2003) find that, compared to publics, FPs are twice as likely to provide "treatment on demand" (wait time of 48 hours or less for treatment entry), but seven times more likely to turn patients away (presumably because of their inability to pay). Alexander, Nahra, and Wheeler (2003) find that publics and NFPs are more likely than FPs both to treat a larger percentage of clients who are unable to pay and to offer clients reduced fees for services rendered. In addition, they find that publics and NFPs are less likely than FPs to shorten treatment periods for their clients because of inability to pay. 
Several studies have shown that FPs are significantly less likely than publics to offer comprehensive services, possibly because FP clientele have less need for these services (Olmstead and Sindelar 2004, Friedmann et al. 2003, Friedmann, Alexander, and D’Aunno 1999, Lee et al 2001). For example, in a recent study, Friedmann et al. (2003) find that FPs are significantly less likely than publics to offer employment counseling, mental health care, routine medical care, and physical examinations. In an earlier study, Friedmann, Alexander, and D’Aunno (1999) found that FPs were less likely than publics to provide TB treatment, HIV/AIDS treatment, and mental health services.

\section{Managed care}

Many studies have found that MC in behavioral health markets is associated with a move away from high-cost inpatient care to less-costly outpatient venues (Ettner et al. 2003, Ettner et al. 2003, Sturm 2000, Steenrod et al. 2001, Frank and McGuire 1997). Lemak and Alexander (2001) find that treatment intensity (months in treatment and number of therapy sessions involved) is negatively affected by the stringency of $\mathrm{MC}$ (average number of visits per patient authorized by MC), but unaffected by the scope of MC (number of different MC oversight activities). In contrast, Ettner et al. (2003) find that MC is associated with longer treatment episodes, more visits per episode, and better outcomes.

Alexander, Nahra, and Wheeler (2003) find that outpatient substance abuse treatment (OSAT) units with either relatively low or high MC penetration are more likely to support access to care by: (1) providing care to a higher percentage of clients unable to pay, and (2) being less likely to shorten treatment because of client inability to pay (OSAT units with midrange MC penetration were least likely to support access to care). And Friedmann et al. (2003) find that 
MC involvement increases the likelihood of both treatment on demand and turning patients away.

D'Ambrosio et al. (2003) and Alexander and Lemak (1997) both find that MC is associated with increased administrative costs to the provider. Alexander, Lemak, and Campbell (2003) find that MC activity has increased among SAT providers affiliated with hospitals and mental health centers (perhaps reflecting a desire on the part of $\mathrm{MC}$ organizations to purchase a more comprehensive array of services from the same provider).

Several studies focus on the relationship between MC and the number or type of services offered at SAT facilities. Friedmann et al. (2003) find that MC is associated with greater availability of mental health services and routine medical care (but not financial counseling, employment counseling, or physical exams). Durkin (2002) finds that MC is associated with a reduction in the likelihood of providing employment counseling and financial counseling, and an increase in the likelihood of providing routine medical care and physical exams. Olmstead, White, and Sindelar (2004) examine a broad array of 26 SAT services and find that: (1) MC causes SAT facilities to offer, on average, approximately two fewer services overall, and (2) this effect is concentrated primarily in tests for infectious diseases (i.e., TB, HIV/AIDs, and STDs).

Finally, McNeese-Smith (1998) reports that 38\% of surveyed SAT program directors in LA County eliminated some services in response to MC, and Rivers (1998) reports that $20 \%$ of surveyed SAT program directors in Miami-Dade County claimed that MC caused reduced availability and accessibility of SAT services. 


\section{CONCEPTUAL FRAMEWORK}

We provide a brief conceptual framework for examining how the impact of MC on SAT service offerings may vary by facility ownership. We draw on several lines of research which together suggest how the impact of managed care may vary by the profit status of the facility. Organizational type in SAT

Theories of why a mixture of ownership types exists in some industries and not others are largely based on market failures, government failures, and voluntary failures (for a summary see Steinberg, 2004). In health care, NFPs and publics are likely to develop due to their charitable goals. In the case of SAT, they may also arise due to the market failure associated with negative externalities from substance abuse. That is, addiction to illicit drugs often produces negative externalities (e.g. crime and spread of disease), thus society should be interested in obtaining effective treatment for drug users.

Providers of different ownership types will have systematically varying goals, opportunities and constraints based on their profit status. These differences can in turn produce differences in client mix, pricing, funding, access to care, range of services offered and behavioral response to MC.

For-profit firms have the goal that is clearest to articulate, they desire to maximize profits for their owners and investors. Thus, for-profit SAT organizations typically are more concerned with efficiency. They may want to attract those clients who will be most profitable for the organization, that is, those who have a favorable combination of relatively low treatment cost but high fees paid. FPs may attract these most desirable clients by providing high quality at a price prohibitively high for those of low income or those with less generous insurance coverage. FPs 
have financial advantages in that they can raise private equity and have fewer constraints on their property rights and transactions (e.g., they can pay managers incentives based on profits).

Not-for-profits' goals are less easily summarized. They may have the goal of "doing good," possibly reflecting the mission of the board, founders or parent organization. Potential donors to these NFPs presumably will have goals compatible with the organization, and they will want to ensure that donations will be used for these causes (rather than be diverted to private gain). Due to their goal of serving communities, NFPs generally are exempt from federal, state, and local taxes on income, property, and purchases. Although NFPs do not have access to equity capital (as do FPs) or to tax revenues (as do publics), they have access to tax-exempt bonds, subsidized loans, and financial contributions that are tax-deductible to the giver (Gray and McNerney 1986, Rosenau and Linder 2003). NFPs are subject to a non-distribution constraint, which restricts the right to pay out organization profit to managers or directors.

Public organizations have broad social goals and are often characterized as the "supplier of last resort" due to their concern with making services available to all individuals, regardless of their ability to pay (Kapur and Weisbrod 2000, Ballou and Weisbrod 2003, Hodgkin et al. 2004). Public providers of SAT may have as their mission to treat the most needy and to treat as many of those in need as the budget will allow. The revenue of publics is based largely on the political budgeting process whereby tax revenues are allocated at the federal and state level (Kapur and Weisbrod 2000, Ballou and Weisbrod 2003). Publics are also subject to a non-distribution constraint.

Thus, differences in profit status related to differences in constraints and opportunities are likely to lead to differences in goals, behavior, client mix and organizational responses to MC. 


\section{Managed care contracting}

If a provider has a MC contract in place, this implies that both the managed care organization (MCO) and the treatment facility came to terms on the MCO's requirements. The SAT facility had to have agreed to the prices offered and other terms (including UR, reporting, etc.) of the MC contract. The decision to agree to the MC contract on the part of a provider would be a function of the characteristics of the facility, including current services offered, current price, and administrative ability to meet reporting and service requirements (Olmstead, White and Sindelar 2004). Viewed from the other side, the MC organization will want to contract with a treatment facility that either already offers, or is willing to offer the quality and services that are required by the MC organization and is also willing and able to accept the price, $\mathrm{UR}$, and reporting requirements.

In some cases, MC may not have any impact on services or price, as the facility either already offers the required mix (a simple matching), ${ }^{1}$ or may have the market power to resist changes. In other cases, MC's pricing and administrative controls may lead to changes in price, quality, services offered, costs, reporting requirements and other.

However, because payment for SAT is made on a per diem or weekly basis, and is typically independent of services offered, the MCO could readily impact the range of services offered. Core services are counseling and urine toxicology. MC may require these services but not be willing to pay for extensive services much beyond core requirements, e.g. medical testing for disease or transportation assistance. The overall impact of MC may be to standardize treatment, increase assessments for UR, and possibly reduce overall treatment quality if prices of MC are

\footnotetext{
${ }^{1}$ For discussions on selective contracting, see Lemak, Alexander, and D'Aunno (2001), Alexander, Nahra and Wheeler (2003), and Alexander, Lemak and Campbell (2003).
} 
lower than the current prices accepted (Dranove and Satterthwaite 2000, Dranove, Satterthwaite and Sindelar 1986, Glazer and McGuire 2002).

\section{Differential impact of $M C$}

MC may operate in very different settings across ownership types due to differences in mission, client mix, regulatory constraints, and facility financing. These differences may mitigate or exacerbate the impact of MC on service offerings. One implication of this is that facilities should be analyzed allowing for a differential response by ownership type. Facilities

that had relatively few services prior to MC may add services required by the MCO (e.g. types of UR). Facilities that are offered a lower price by MC may reduce service offerings beyond core services. MC may be unwilling to reimburse for services it deems either cost-ineffective or not "medically necessary" for treating substance abuse (e.g., ancillary services such as employment counseling, transportation assistance and testing for diseases).

Public facilities tend to treat clients that have relatively more problems (including social, economic, and health-related) and offer, on average, a wider range of SAT services than do forprofit facilities (Olmstead, White, and Sindelar 2004, Friedmann et al. 2003, Lee et al. 2001, Friedmann, Alexander and D'Aunno 1999). Publics also tend to see themselves as the "supplier of last resort" (Hodgkin et al. 2004, Ballou and Weisbrod 2003, Kapur and Weisbrod 2000). And public facilities have more governmental financing, specifically block grants that provide a lump sum to the facility and expect a large number of clients to be treated (Wheeler and Nahra 2000, Rodgers and Barnett 2000). Although it is possible that MC would cause publics to offer an even wider range of services—say, by requiring more types of assessments-we expect that MC will cause publics to narrow their range of services for the following reasons. First, MC may not reimburse for services that are either cost-ineffective, not "necessary" for substance 
abuse treatment (e.g., transportation assistance, child care), or covered by another part of the health plan (e.g., medical services such as TB testing). Second, MC may reduce overall reimbursement levels for offered services such that publics must offset lost revenues by eliminating "noncore" services (e.g., ancillary social and medical services)

Private for-profit facilities have tended to offer the fewest services and tend to serve clients who are privately insured (or able to pay for care out-of-pocket) and have relatively fewer comorbidities. Thus MC might result in more services offered at FPs as the "quality of care" (here measured as number of services offered) is standardized across providers. Additional assessments might be required for UR, for example. Services offered might also increase with $\mathrm{MC}$ if there is a shift by private pay patients from inpatient facilities to outpatient facilities; more intensive services may be required for those who would otherwise be treated on an inpatient basis. The net impact of MC might be to encourage FPs to seek out new types of clients to make more efficient use of excess capacity. ${ }^{2}$ On the other hand, MC could have no effect if it is just a matching process, with FPs being most able to provide the reporting required by MC.

Given that NFPs are a hybrid of FPs and publics, it is difficult to predict the effect of MC on the range of services offered by NFPs. A reasonable conjecture is that the effect of MC on NFPs will lie somewhere between its effect on FPs and publics. Thus, the net impact is an empirical issue, one which we address.

\footnotetext{
${ }^{2}$ FPs typically have excess capacity, as compared to publics that typically operate at or over-capacity. Being profitmaximizers, FPs should already be offering the optimal mix of services for their targeted client base. However, if revenues are reduced by MC, FPs may need to cover fixed costs by expanding their customer base to serve clients that offer a lower rate of return than previously considered acceptable. These new clients, in turn, will likely require additional services (not currently offered) to be attracted to the FPs.
} 


\section{METHODS}

Data

Data on SAT facilities were obtained from the 2000 National Survey of Substance Abuse Treatment Services (NSSATS), a national survey administered by the Substance Abuse and Mental Health Services Administration (SAMHSA) that collects information on the location, characteristics, and use of SAT facilities and services in the US (USDHHS 2002b). The list frame for the 2000 NSSATS is the Inventory of Substance Abuse Treatment Services (I-SATS), a continuously-updated census of all known SAT facilities, both public and private, throughout the US and its territories. Analyses were performed separately for facilities with public ownership, private for-profit ownership, and private not-for-profit ownership.

Of the original census of 14,622 SAT facilities deemed eligible for the survey, 13,749 (94 percent) completed the survey. ${ }^{3}$ Of these, we exclude facilities located in other US jurisdictions $(n=120),{ }^{4}$ owned by federal or tribal governments $(n=481)$, or offering detoxification services only $(\mathrm{n}=41)$. An additional 2,594 facilities are excluded due to missing data, resulting in a final study sample comprising 10,513 SAT facilities. $^{5}$

We supplement the 2000 NSSATS data on facility characteristics with county-specific data from the 2002 Area Resource File (USDHHS 2002a), a database containing information on population and managed care activity in the US. ${ }^{6}$

\footnotetext{
${ }^{3}$ Facilities were deemed ineligible for the survey if they were not providing substance abuse treatment as of October 1,2002 or treated incarcerated clients only.

${ }^{4}$ Other US jurisdictions include the territories of American Samoa and Guam, the Federated States of Micronesia, the Republic of Palau, the Commonwealth of Puerto Rico, and the Virgin Islands.

${ }^{5}$ Facilities are not missing data in a systematic fashion, so we do not expect any bias due to missing data.

${ }^{6}$ The 2002 Area Resource File uses the InterStudy County Surveyor Database for the number of HMO enrollees in each county.
} 


\section{Outcomes}

The 2000 NSSATS records whether a facility offers each of twenty-six different SAT services. Accordingly, we use twenty-seven outcome variables to measure service offerings at a facility. The first outcome variable is the total number of services offered at the facility (ranging from 1 to 26), while the remaining twenty-six outcome variables are binary indicators, each one corresponding to the presence of a specific service at the facility. NSSATS groups the twentysix individual services into five categories: assessment, therapy/counseling, medical testing, transitional, and other services. Table 1 lists each of the outcome variables used in this study.

\section{Table 1: Summary Statistics of Outcome Variables}

\section{Regressors}

We control for a wide variety of important facility and county-specific characteristics. Facility characteristics include the presence of managed care, focus, setting, modality, accreditation, licensure, size, types of payment accepted, and willingness to offer payment assistance. Our measure of managed care is whether or not the facility has a relationship with a managed care organization, $M C$, set to 1 if a facility has at least one agreement or contract with a managed care organization to provide substance abuse treatment services, and 0 otherwise. Facility foci include substance abuse, mental health, general health, mixed mental health and substance abuse, and other. Settings include hospital, solo practice, and halfway house. Modalities include hospital inpatient, non-hospital residential, outpatient, and methadone/LAAM. Finally, types of payment accepted include cash, private health insurance, Medicaid, Medicare, state-financed health insurance, and public funds (not including Medicaid and Medicare). 
County-specific characteristics include population size, population density (people per square mile), metropolitan area, competition among facilities (measured using Herfindahl indices), and managed care activity (measured using the number of Medicare managed care and HMO enrollees in the county). Table 2 lists each of the regressors used in this study. We control for these variables based on earlier studies and the conceptual framework.

\section{Table 2: Summary Statistics of Regressors}

\section{Estimation}

We first present descriptive data by facility ownership type (i.e., publics, FPs, and NFPs). Facilities are further subdivided by the presence of managed care. Proportions are given for categorical variables and means for continuous variables. By comparing the characteristics of facilities with and without MC, we can get a sense of whether differential selection of facilities into relationships with $\mathrm{MC}$ is likely to confound the relationship between $\mathrm{MC}$ and service offerings.

We then use a two-equation instrumental variables (IV) approach to estimate the effect of MC on the outcome variables. This approach allows us to account for possible endogeneity between a facility's involvement in MC and service offerings. Endogeneity would be present, for example, if managed care is attracted to facilities with an unobserved (to the analyst) propensity to offer more (or fewer) services. For example, MC may be attracted to facilities with administrative sophistication, a trait which is unobserved to the researcher but correlated with both service offerings and MC. With valid instruments, the IV approach accounts for endogeneity and produces consistent estimates of the causal effect of managed care on service offerings (Davidson and MacKinnon 1993). The IV approach is used frequently in economic 
applications and is becoming increasingly common in healthcare evaluations (McClellan and Newhouse 2000).

We use the following 2-equation model:

(1) $\quad Y=\beta X+\gamma M C+\varepsilon$

(2) $\quad M C=\alpha X+\kappa Z+\mu$

where $Y$ is the outcome variable under study (i.e., either total number of services at the facility or presence of a specific service at the facility), $M C$ is a dummy variable indicating the presence of managed care at the facility, $X$ is a vector of facility and environmental characteristics, $\varepsilon$ is the error term for equation (1) that captures unobserved determinants of $Y, Z$ is a vector of instruments that influence the presence of managed care but are uncorrelated with $\varepsilon$, and $\mu$ is the error term for equation (2).

When the outcome variable in (1) is total number of services, the two-equation system is estimated using a full-maximum-likelihood 'treatment effects' model (Maddala 1983) that considers the effect of an endogenously chosen binary treatment (managed care) on another endogenous, fully-observed, continuous variable (number of offered services). When the outcome variable in (1) is the presence of a specific service (a binary indicator), the two-equation system is estimated using a maximum likelihood bivariate probit model (Maddala 1983). In both models, facilities are clustered by county to account for possible spatial correlation amongst facilities operating in the same geographic area.

We estimate separate models for each group of facilities (publics, FPs, and NFPs). Specifically, we estimate a treatment effects model for the total number of services and twentysix separate bivariate probit models, one for each of the twenty-six specific services. The same explanatory variables are used across the different ownership types. By estimating separate 
regressions for each profit status, we allow the coefficients on all the independent variables to differ by ownership type. Tables are presented giving the "predictive margins."7

The IV approach requires finding one or more variables to be used as instruments, Z, that substantially affect MC but have no direct impact on Y. We use two different county-specific instruments in our model: number of Medicare MC enrollees and number of HMO enrollees. Given that we control for county population and density, the number of Medicare MC (or HMO) enrollees is, in essence, a percentage.

Both instruments plausibly satisfy the first correlation condition inasmuch as SAT facilities in counties with a large number ("percentage") of Medicare MC (or HMO) enrollees are more likely to have agreements or contracts with managed care than their counterparts in counties with relatively few Medicare MC (or HMO) enrollees. Similar county-specific environmental factors (e.g., local tastes, state/local laws, demographics) could cause this correlation. Spillover effects of many kinds could increase the favorable climate for managed care in SAT. As for the second condition, it seems plausible that the number of Medicare MC enrollees in a given county is unlikely to directly influence the service-offering decisions at SAT facilities in that county. Medicare covers primarily those 65 or older and SAT facilities treat very few elderly (approximately $1.5 \%$ of SAT clients are 65 or older). Similarly, there is likely to be relatively little overlap between HMO enrollees and SAT clients (about 11 percent of the total population in the US is drug dependent and only a fraction of them seek substance abuse treatment).

We assess formally the validity of our instruments by testing for the presence of bias due to weak instruments and conducting a standard test of overidentification.

\footnotetext{
${ }^{7}$ Predictive margins measure the difference in the expected value of the outcome when the MC indicator is changed from 0 to 1 and all other regressors are held constant at their original values.
} 


\section{RESULTS}

\section{Descriptive data by facility ownership}

Table 1 shows that, for each ownership type, $\mathrm{MC}$ is associated with more total services and an increased likelihood of offering most of the specific services. For example, MC is associated with 2.2 more services in FPs, 1.2 more services in NFPs, and 1.0 more services in publics. However, as shown in Table 2, facilities with and without MC differ systematically in other important ways as well. For each ownership type, for example, facilities with MC contracts are more likely to be larger, affiliated with a hospital, accredited, and to focus on both substance abuse and mental health. These factors could be associated with the availability of more services, thereby explaining the positive association between MC and services. Thus, we need to control for relevant covariates when estimating the impact of MC on service offerings. Moreover, MC is likely to be endogenously determined. That is, there may be unobserved factors that affect both the availability of services and the presence of MC. We now turn to the IV models.

IV specification controlling for facility characteristics

(a) Number of services

When we control for observed covariates and use instrumental variables to account for possible endogeneity, the impact of $\mathrm{MC}$ on total services varies in magnitude and direction by facility ownership. Table 3 shows that, on average, MC significantly widens the range of services offered at FPs by 3.8 services, has no significant impact on the total number of services offered at NFPs, and significantly narrows the range of services offered at publics by 3.7 services. These findings are quite different from the associations portrayed in the raw data in Table 1. 


\section{Tables 3 and 3A: IV Models: Total Services - By Ownership}

F-statistics for both the FP and NFP specifications are above 10.0, indicating that there is unlikely to be any bias due to weak instruments in these models (Staiger and Stock 1997). Although there may be some bias due to weak instruments in the model for publics, this bias is probably small inasmuch as the corresponding F-statistic is statistically significant and much larger than 1.0 (Bound, Jaeger and Baker 1995). Importantly, all three models pass the standard test of over-identification (Davidson and MacKinnon 1993, Kennedy 1998, Greene 2003), adding reassurance that equation (1) is specified correctly and that both instruments are valid. ${ }^{8}$ (b) Specific services

Table 4 displays the results for the IV models corresponding to specific services offered by each ownership type. We report only the coefficients of MC and suppress the coefficients on the control variables to focus on the key results.

\section{Table 4: Coefficients on Managed Care for Specific Services - By Ownership}

The differential impact of MC on the total number of services offered by FPs and publics appears to be concentrated primarily in ancillary service offerings. That is, MC significantly increases the likelihood that FPs offer ancillary services such as discharge planning, housing assistance, transportation assistance, and referrals to other transitional services. In contrast, MC significantly decreases the likelihood that publics offer ancillary services such as tests for medical diseases (HIV, TB), HIV/AIDs education, employment training, child care, and referrals to other transitional services.

\footnotetext{
${ }^{8}$ The test statistic is calculated as $\mathrm{N}$ times the uncentered $\mathrm{R}^{2}$ from regressing the IV residuals on all the instruments, and is distributed as a chi-square with degrees of freedom equal to the number of instruments in excess of the number of explanatory variables.
} 
The effect of MC on specific services offered by NFPs is mixed. On one hand, MC significantly increases the likelihood that NFPs offer substance abuse assessment (though the effect is very small), urine screens, relapse prevention groups and discharge planning. On the other hand, MC significantly decreases the likelihood that NFPs offer outcome follow-up, employment training, and tests for medical diseases (STDs, TB).

MC does not appear to have a differential impact across ownership types on assessment, therapy, or counseling services. Although MC significantly impacts the likelihood of offering several of these types of services in certain cases, there is no systematic pattern by ownership type. This is not surprising, however, given that these services form the necessary core of SAT and so are offered by the vast majority of facilities regardless of ownership type or the presence of MC.

\section{DISCUSSION}

One possible explanation for the differential impact of MC across facility ownership types is that MC results in standardization across facilities of different profit status. That is, in the absence of MC, we observe that FPs offer the narrowest range of services, publics the widest, and NFPs fall in the middle. MC could be a standardizing force making the service offerings more similar across ownership types. Thus, for-profits add services while publics reduce them.

Another possible explanation stems from the purported existence of a two-tiered substance abuse treatment system, in which FPs typically serve "tier 1" clients while publics tend to treat "tier 2" clients. Public facilities may respond to cuts in reimbursements by eliminating "non-essential" ancillary services (e.g., employment training, HIV/AIDs education) with the goal of being able to continue to treat large numbers of the needy. ${ }^{9}$ In contrast, FP facilities might

\footnotetext{
${ }^{9}$ This explanation is consistent with the "supplier of last resort" model of public healthcare organizations.
} 
respond to revenue cuts by attracting those "tier 2" clients who may now be financially appealing to them. ${ }^{10}$ FPs would need to offer additional services to attract these "tier 2" clients.

There are other possible explanations as well. For example, it may be that public and private SAT facilities have contracts with different types of MC organizations, which in turn may have different goals. For example, managed care associated with state funding (e.g. block grants) may want to reduce the range of services offered in order to treat as many people as possible with limited funds. In contrast, private health insurance may have quality of care as a more important goal, and may therefore require additional types of treatment to increase effectiveness and offset other medical expenses.

The move from inpatient to outpatient care associated with MC may also differentially impact facilities. If, for example, FPs treat more clients who, in the absence of MC, would be in inpatient care, then their client base would need a broader range of services in the presence of MC. Note that FPs may be more likely to treat those who otherwise would have been in inpatient care because their client base tends to have more generous coverage (which, in turn, may be more likely to cover inpatient care but for MC controls).

Empirically identifying which of the above reasons best explains the observed differential impacts, however, is beyond the capability of our data and is also beyond the scope of our paper.

The finding that MC significantly decreases ancillary service offerings at public SAT facilities is consistent with the view that MC reduces payments to the provider and encourages core services at the expense of ancillary (wraparound) services. This is also consistent with Kapur and Weisbrod (2004) and Hodgkin et al. (2004), both of whom found that public healthcare organizations respond to funding cuts by reducing quality of care, as opposed to

\footnotetext{
${ }^{10}$ Being profit-maximizers, FPs should already be offering the optimal mix of services for their targeted client base. However, if revenues are reduced by MC, FPs may need to cover their fixed costs in the short run by expanding their customer base to serve clients that offer a lower rate of return than previously considered acceptable.
} 
turning away clients (i.e., publics view themselves as the "supplier of last resort"). ${ }^{11}$ It also supports Alexander, Lemak, and Campbell's (2003) speculation that as MC expands into the public SAT sector, cost containment may reduce the range and type of services available to vulnerable populations.

That MC significantly increases ancillary service offerings at for-profit SAT facilities stands somewhat in contrast to Durkin (2002) and Friedmann et al. (2003). Durkin (2002) found that $\mathrm{MC}$ is associated with a reduction in the likelihood of providing employment counseling and financial counseling, but an increase in the likelihood of providing routine medical care and physical exams. Friedmann et al. (2003) found that MC is associated with greater availability of mental health services and routine medical care, but not financial counseling, employment counseling, or physical exams. However, since both of these studies use a one-equation logistic model that does not account for the endogeneity between MC and service offerings, these results may be biased.

This study is subject to a number of limitations. First, NSSATS records managed care as a binary variable. Thus, we do not know the intensity, strength, or types of MC mechanisms at each facility. Second, we know only if a service is offered-we do not know whether the service has been received, who receives it, nor the intensity nor quality of the service. It is important to recognize, however, that using binary indicators of specific services and $\mathrm{MC}$ is a conservative approach. That is, the relatively blunt nature of binary variables could bias against finding significant results. Third, NSSATS does not collect data on client characteristics. Thus, we

\footnotetext{
${ }^{11}$ We consider the range of service offerings to be one component in the quality of care. Research shows that a greater range of services increases the effectiveness of care (NIDA 1999, McLellan et al. 1998, McLellan et al. 1999). Payment to a SAT facility is not, however, typically explicitly determined by the number or range of services offered, but rather payment is made on a per diem or weekly basis. Thus, the range of services may be more akin to higher amenities or quality of care that are not paid for directly.
} 
cannot test how much, if any, of the total differential impact of MC on FPs and publics is due to a "two-tiered" SAT system, as speculated above, or to other factors (e.g., standardization). Indeed, this is an important area for future research. Finally, there may be some bias in the results for publics due to weak instruments. However, we expect this bias to be small given that the corresponding F-statistic (in Table 3) is both significant and much larger than 1.0 (Bound, Jaeger and Baker 1995).

Although we recognize that the aforementioned NSSATS data limitations constrain our analyses, offsetting these limitations is the fact that we use almost the entire universe of SAT facilities in our study, including data on a wide range of specific service offerings. Thus, our statistical power is high and our results are nationally generalizable. Further, although we have only a crude measure of $\mathrm{MC}$, we are able to move the literature forward by discovering the interesting differential impacts of MC by provider profit status. This adds to both the SAT and ownership type literatures. Although we cannot identify with certainty the specific mechanisms underlying the observed differential impacts, we pave the way for future research to study such mechanisms.

\section{CONCLUSIONS}

This study shows that the impact of MC on SAT service offerings depends on facility ownership. Specifically, MC significantly increases the number of services offered at private for-profits, has no significant effect on the number of services offered at private not-for-profits, and significantly decreases the number of services offered at public SAT facilities. Moreover, it appears that the differential impact of MC across ownership types is concentrated in ancillary service offerings (e.g., tests for medical diseases, employment training, housing assistance, child care, referrals to other transitional services). Our findings can be interpreted as causal, subject to 
the above limitations, because they are derived from IV models that not only control for relevant covariates but also adjust for potential endogeneity between MC and service offerings. The study adds to the existing SAT literature by demonstrating that the impact of MC on SAT service offerings differs in magnitude and direction by facility ownership, and by quantifying these differential impacts. The study also adds to the empirical literature on mixed profit status industries by extending the analyses to SAT.

Our findings raise policy concerns because a reduced range of ancillary service offerings in public facilities could result in unmet needs for SAT clients in these facilities. This, in turn, could lead to worse treatment outcomes for those in SAT as well as an increase in the negative externalities associated with drug abuse (e.g., unemployment, crime, spread of infectious diseases). However, the impact on society of the increase in the range of services offered by FPs is unclear. If, for example, FPs are attracting clients who would not otherwise have received treatment elsewhere, then the effect of MC is beneficial to both the clients and society. On the other hand, if FPs are cream-skimming the "healthier and wealthier" tier-2 clients from NFP and public facilities, then this would leave NFPs and publics with a client base that is less able to pay for services, possibly forcing these facilities to cut service offerings more than would otherwise be the case. 


\section{REFERENCES}

Alexander, J., and C. Lemak. 1997. "The Effects of Managed Care on Administrative Burden in Outpatient Substance Abuse Treatment Units." Medical Care 35 (5):1060-8.

Alexander, J., C. Lemak, and C. Campbell. 2003. "Changes in Managed Care Activity in Outpatient Substance Abuse Treatment Organizations, 1995-2000." Journal of Behavioral Health Sciences and Research 30 (4):369-81.

Alexander, J., T. Nahra, and J. Wheeler. 2003. "Managed Care and Access to Substance Abuse Treatment Services." Journal of Behavioral Health Services and Research 30 (2):161-75.

Ballou, J., and B. Weisbrod. 2003. "Managerial Rewards and the Behavior of For-Profit, Governmental, and Nonprofit Organizations: Evidence from the Hospital Industry." Journal of Public Economics 87 (9-10):1895-20.

Bound, J., D. Jaeger, and R. Baker. 1995. "Problems with Instrumental Variables Estimation When the Correlation Between the Instruments and the Endogenous Explanatory Variable is Weak." Journal of the American Statistical Association 90 (430):443-50.

Carlson, M., W. Gallo, and E. Bradley. 2004. "Ownership Status and Patterns of Care in Hospice - Results from the National Home and Hospice Care Survey." Medical Care 42 (5):4328.

D’Ambrosio, R., F. Mondeaux, R. Gabriel, and K. Laws. 2003. “Oregon's Transition to a Managed Care Model for Medicaid-Funded Substance Abuse Treatment: Steamrolling the Glass Menagerie." Health and Social Work 28 (2) 126-36.

Davidson, R., and J. MacKinnon. 1993. Estimation and Inference in Econometrics. New York: Oxford University Press.

Dranove, D., and M. Satterthwaite. 2000. "The Industrial Organization of Health Care Markets." In Handbook of Health Economics, vol. 1A, edited by A.J. Culyer and J.P. Newhouse, pp. 1093-35. Amsterdam: Elsevier.

Dranove D., M. Satterthwaite, and J. Sindelar. 1986. "Preferred Provider Organizations: Injecting Price Competition into the Hospital Market." Inquiry 23 (4): 419-431.

Durkin, E. 2002. “An Organizational Analysis of Psychosocial and Medical Services in Outpatient Drug Abuse Treatment Programs." Social Service Review 76 (3):406-29.

Ettner, S., M. Argeriou, D. McCarty, J. Dilonardo, and H. Liu. 2003. "How Did the Introduction of Managed Care for the Uninsured in Iowa Affect the Use of Substance Abuse Services?" Journal of Behavioral Health Services and Research 30 (1):26-40 
Ettner, S., G. Denmead, J. Dilonardo, H. Cao, and A. Belanger. 2003. “The Impact of Managed Care on the Substance Abuse Treatment Patterns and Outcomes of Medicaid Beneficiaries: Maryland's HealthChoice Program." Journal of Behavioral Health Services and Research 30 (1):41-62.

Frank, R., and T. McGuire. 1997. "Savings from a Medicaid Carve Out for Mental Health and Substance Abuse Services in Massachusetts." Psychiatry Services 48 (9):1147-52.

Friedmann, P., J. Alexander, and T. D'Aunno. 1999. "Organizational Correlates of Access to Primary Care and Mental Health Services in Drug Abuse Treatment Units." Journal of Substance Abuse Treatment 16 (1):71-80.

Friedmann, P., S. Lemon, E. Durkin, and T. D'Aunno. 2003. "Trends in Comprehensive Service Availability in Outpatient Drug Abuse Treatment." Journal of Substance Abuse Treatment 24 (1):81-8.

Friedmann, P., S. Lemon, M. Stein, and T. D'Aunno. 2003. “Accessibility of Addiction Treatment: Results from a National Survey of Outpatient Substance Abuse Treatment Organizations." Health Services Research 38 (3):887-03.

Glazer, J., and T. McGuire. 2002. "Multiple Payers, Commonality and Free-Riding in Health Care: Medicare and Private Payers." Journal of Health Economics 21 (6):1049-1069.

Gould, F., M. Levine, and A.T. McLellan. 2000. "Treating the Substance-Abusing Patient in the Public Sector: 'Medical Necessity' Versus 'Social Necessity and Social Responsibility' in the Philadelphia Target Cities Demonstration Project." Journal of Substance Abuse Treatment 18 (1):75-7.

Gray, B., and W. McNerney. 1986. "For-Profit Enterprise in Health Care." New England Journal of Medicine 314 (23):1523-8.

Greene, W. 2003. Econometric Analysis, $5^{\text {th }}$ ed. Upper Saddle River, NJ: Prentice Hall.

Hansmann, H. 1980. “The Role of Nonprofit Enterprise.” Yale Law Journal 89 (5):835-01.

Harwood, H., D. Fountain, and G. Livermore. 1998. The Economic Costs of Alcohol and Drug Abuse in the United States, 1992. Rockville MD: National Institute on Drug Abuse, NIH Publication No 98-4327.

Hirth, R. 1999. "Consumer Information and Competition Between Nonprofit and For-profit Nursing Homes." Journal of Health Economics 18 (2):219-40.

Hodgkin, D., D. Shepard, Y. Anthony, and G. Strickler. 2004. "A Publicly Managed Medicaid Substance Abuse Carve-Out: Effects on Spending and Utilization." Administration and Policy in Mental Health 31 (3):197-17. 
Institute of Medicine. 1990. Treating Drug Problems—Volume 1: A Study of the Evolution, Effectiveness, and Financing of Public and Private Drug Treatment Systems. Washington DC: National Academy Press.

Kapur, K., and B. Weisbrod. 2000. "The Roles of Government and Nonprofit Suppliers in Mixed Industries.” Public Finance Review 28 (4):275-08.

Kennedy, P. 1998. A Guide to Econometrics, $4^{\text {th }}$ ed. Cambridge, MA: MIT Press.

Lee, M.T., S. Reif, G.A. Rigger, H.F. Levin, and C.M. Horgan. 2001. "Access to Services in the Substance Abuse Treatment System. Variations by Facility Characteristics." Recent Developments in Alcoholism, vol. 15, Services Research in the Era of Managed Care, edited by M. Gallanter, pp.137-56. New York: Kluwer Academic/Plenum

Lemak, C., and J. Alexander. 2001. "Managed Care and Outpatient Substance Abuse Treatment Intensity." Journal of Behavioral Health Services and Research 28 (1):12-29.

Lemak C., J. Alexander, and T. D'Aunno. 2001. 'Selective Contracting in Managed Care: The Case of Substance Abuse Treatment." Medical Care Research and Review 58 (4):455-81.

Lindrooth, R. and B. Weisbrod. 2004. "Do Nonprofit and For-profit Hospices Really Differ? An Analysis of the Hospice Industry." Medical University of South Carolina, Center for Health Economic and Policy Studies (CHEPS), Working Paper \#005-04.

Maddala, G. 1983. Limited-Dependent and Qualitative Variables in Econometrics. New York: Cambridge University Press.

Marsh, J., T. D'Aunno, and B. Smith. 2000. "Increasing Access and Providing Social Services to Improve Drug Abuse Treatment for Women with Children." Addiction 95 (8):1237-47.

McClellan, M., and J. Newhouse. 2000. "Introduction: Overview of the Special Supplement Issue." In Instrumental Variables Analysis: Applications in Health Services Research: A Special Supplement to HSR, edited by M. McClellan and J. Newhouse. Health Services Research 35 (5), Part II.

McLellan, A.T., I. Arndt, D. Metzger, G. Woody, and C. O'Brien. 1993. "The Effects of Psychosocial Services in Substance-Abuse Treatment.” JAMA 269 (15):1953-9.

McLellan, A.T., T. Hagan, K. Meyers, M. Levine, F. Gould, M. Bencivengo, J. Durell, and J. Jaffe. 1998. "Supplemental Social Services Improve Outcomes in Public Addiction Treatment." Addiction 93 (10):1489-99.

McLellan, A.T., M. Levine, T. Hagan, K. Meyers, M. Randall, F. Gould, M. Bencivengo, and J. Durell. 1999. "Does Clinical Case Management Improve Outpatient Addiction Treatment?" Drug and Alcohol Dependence 55 (1-2):91-03. 
McNeese-Smith, D.K. 1998. "Program Directors' Views of the Effect of Managed Care on Substance Abuse Programs in Los Angeles County." Psychiatric Services 49 (10):13239.

Milby, J., J. Schumacher, J. Raczynski, E. Caldwell, M. Engle, M. Michael, and J. Carr. 1996. "Sufficient Conditions for Effective Treatment of Substance Abusing Homeless Persons." Drug and Alcohol Dependence 43 (1-2):39-47.

National Consensus Development Panel on Effective Medical Treatment of Opiate Addiction. 1998. "Effective Medical Treatment of Opiate Addiction." JAMA 280 (22):1936-43.

National Institute on Drug Abuse (NIDA), National Institutes of Health, U.S. Department of Health and Human Services. 1999. Principles of Drug Addition Treatment: A Research Based Guide. NIH Publication No. 99-4180. Washington, DC: National Institutes of Health.

Newhouse, J. 1970. "Toward a Theory of Nonprofit Institutions: An Economic Model of a Hospital.” American Economic Review 60 (1):64-74.

Office of National Drug Control Policy. 1996. "Treatment Protocol Effectiveness Study: A White Paper of the Office of National Drug Control Policy." Journal of Substance Abuse Treatment 13 (4):295-20.

Office of National Drug Control Policy. 2001. The Economic Costs of Drug Abuse in the US, 1992-1998. Publication no. NCJ-190636. Washington DC: Executive Office of the President.

Olmstead, T., and J. Sindelar. 2004. "To What Extent Are Key Services Offered in Treatment Programs for Special Populations?" Journal of Substance Abuse Treatment 27 (1):9-15.

Olmstead, T., W. White, and J. Sindelar. 2004. "The Impact of Managed Care on Substance Abuse Treatment Services." Health Services Research 39 (2):319-45.

Rivers, J. 1998. "Services for Substance Abusers in a Changing Health Care System." American Behavioral Scientist 41 (8):1136-56.

Rodgers, J., and P. Barnett. 2000. "Two Separate Tracks? A National Multivariate Analysis of Differences Between Public and Private Substance Abuse Treatment Programs." American Journal of Drug and Alcohol Abuse 26 (3):429-42.

Rosenau, P., and S. Linder. 2003. "Two Decades of Research Comparing For-Profit and Nonprofit Health Provider Performance in the United States." Social Science Quarterly 84 (2):219-41.

Smith, B., and J. Marsh. 2002. "Client-Service Matching in Substance Abuse Treatment for Women with Children." Journal of Substance Abuse Treatment 22 (3):161-8. 
Staiger, D. and J. Stock. 1997. "Instrumental Variables Regression with Weak Instruments." Econometrica 65 (3):557-86.

Steenrod, S., A. Brisson, D. McCarty, and D. Hodgkin. 2001. "Effects of Managed Care on Programs and Practices for the Treatment of Alcohol and Drug Dependence." Recent Developments in Alcoholism, vol. 15, Services Research in the Era of Managed Care, edited by M. Gallanter, pp.51-71. New York: Kluwer Academic/Plenum.

Steinberg, R. 2004. "Economic Theories of Nonprofit Organizations.” Prepared for The Nonprofit Sector: A Research Handbook, $2^{\text {nd }}$ ed., edited by W. Powell and R. Steinberg.

Sturm, R. 2000. "Managed Care Risk Contracts and Substance Abuse Treatment.” Inquiry 37 (2):219-25.

U.S. Department of Health and Human Services, Health Resources and Services Administration, Bureau of Health Professions, National Center for Health Workforce Analysis. 2002a. Area Resource File. Washington, DC: U.S. Department of Health and Human Services.

U.S. Department of Health and Human Services, Substance Abuse and Mental Health Services Administration, Office of Applied Studies. 2002b. National Survey of Substance Abuse Treatment Services (N-SSATS), 2000: [United States] [Computer file]. ICPSR version. Arlington, VA: Synectics for Management Decisions, Inc. [producer]. Ann Arbor, MI: Inter-University Consortium for Political and Social Research [distributor].

Weisbrod, B. 1998. The Nonprofit Economy. Cambridge, MA and London: Harvard University Press.

Wheeler, J. and T. Nahra. 2000. "Private and Public Ownership in Outpatient Substance Abuse Treatment: Do We Have a Two-Tiered System?" Administration and Policy in Mental Health 27 (4):197-09. 


\begin{tabular}{|c|c|c|c|c|c|c|c|c|}
\hline \multirow[b]{3}{*}{ Variable Name } & \multirow[b]{3}{*}{ Definition } & \multirow{3}{*}{$\begin{array}{c}\begin{array}{c}\text { Full } \\
\text { Sample }\end{array} \\
\mathrm{N}=10,513\end{array}$} & \multicolumn{6}{|c|}{ Ownership Type } \\
\hline & & & \multicolumn{2}{|c|}{ For Profit } & \multicolumn{2}{|c|}{ Not for Profit } & \multicolumn{2}{|c|}{ Public } \\
\hline & & & $\begin{array}{c}\mathrm{MC}=0 \\
\mathrm{~N}=1,283\end{array}$ & $\begin{array}{c}\mathrm{MC}=1 \\
\mathrm{~N}=1,630\end{array}$ & $\begin{array}{c}\mathrm{MC}=0 \\
\mathrm{~N}=2,753\end{array}$ & $\begin{array}{c}\mathrm{MC}=1 \\
\mathrm{~N}=3,694\end{array}$ & $\begin{array}{l}\mathrm{MC}=0 \\
\mathrm{~N}=645\end{array}$ & $\begin{array}{l}\mathrm{MC}=1 \\
\mathrm{~N}=508\end{array}$ \\
\hline Total Services & $\begin{array}{l}\text { Total number of services offered } \\
\text { at SAT facility }\end{array}$ & $\begin{array}{l}13.70 \\
(4.76)\end{array}$ & $\begin{array}{l}10.67 \\
(4.44)\end{array}$ & $\begin{array}{l}12.88 \\
(4.59)\end{array}$ & $\begin{array}{l}13.60 \\
(4.68)\end{array}$ & $\begin{array}{l}14.78 \\
(4.51)\end{array}$ & $\begin{array}{l}14.54 \\
(4.54)\end{array}$ & $\begin{array}{l}15.58 \\
(4.51)\end{array}$ \\
\hline \multicolumn{9}{|l|}{ Assessment } \\
\hline Subst abuse assessment & $\begin{array}{l}0-1 \text { dummy variable, }=1 \text { if facility } \\
\text { offers substance abuse assessment }\end{array}$ & $\begin{array}{c}0.93 \\
(0.25)\end{array}$ & $\begin{array}{c}0.91 \\
(0.28)\end{array}$ & $\begin{array}{c}0.97 \\
(0.18)\end{array}$ & $\begin{array}{c}0.87 \\
(0.34)\end{array}$ & $\begin{array}{c}0.97 \\
(0.17)\end{array}$ & $\begin{array}{c}0.92 \\
(0.27)\end{array}$ & $\begin{array}{c}0.98 \\
(0.15)\end{array}$ \\
\hline Mental health assessment & $\begin{array}{l}0-1 \text { dummy variable, }=1 \text { if facility } \\
\text { offers mental health assessment }\end{array}$ & $\begin{array}{c}0.43 \\
(0.49)\end{array}$ & $\begin{array}{c}0.27 \\
(0.44)\end{array}$ & $\begin{array}{c}0.53 \\
(0.50)\end{array}$ & $\begin{array}{l}0.29 \\
(0.46)\end{array}$ & $\begin{array}{l}0.50 \\
(0.50)\end{array}$ & $\begin{array}{l}0.48 \\
(0.50)\end{array}$ & $\begin{array}{c}0.60 \\
(0.49)\end{array}$ \\
\hline \multicolumn{9}{|l|}{ Therapy/Counseling } \\
\hline Family counseling & $\begin{array}{l}0-1 \text { dummy variable, }=1 \text { if facility } \\
\text { offers family counseling }\end{array}$ & $\begin{array}{c}0.78 \\
(0.42)\end{array}$ & $\begin{array}{c}0.64 \\
(0.48)\end{array}$ & $\begin{array}{c}0.90 \\
(0.30)\end{array}$ & $\begin{array}{c}0.67 \\
(0.47)\end{array}$ & $\begin{array}{l}0.85 \\
(0.36)\end{array}$ & $\begin{array}{c}0.74 \\
(0.44)\end{array}$ & $\begin{array}{l}0.85 \\
(0.36)\end{array}$ \\
\hline Group therapy & $\begin{array}{l}0-1 \text { dummy variable, }=1 \text { if facility } \\
\text { offers group therapy }\end{array}$ & $\begin{array}{l}0.89 \\
(0.31)\end{array}$ & $\begin{array}{c}0.81 \\
(0.39)\end{array}$ & $\begin{array}{l}0.86 \\
(0.35)\end{array}$ & $\begin{array}{l}0.88 \\
(0.33)\end{array}$ & $\begin{array}{l}0.93 \\
(0.25)\end{array}$ & $\begin{array}{l}0.92 \\
(0.27)\end{array}$ & $\begin{array}{l}0.95 \\
(0.22)\end{array}$ \\
\hline Individual therapy & $\begin{array}{l}0-1 \text { dummy variable, }=1 \text { if facility } \\
\text { offers individual therapy }\end{array}$ & $\begin{array}{l}0.95 \\
(0.22)\end{array}$ & $\begin{array}{c}0.93 \\
(0.25)\end{array}$ & $\begin{array}{l}0.96 \\
(0.19)\end{array}$ & $\begin{array}{l}0.93 \\
(0.26)\end{array}$ & $\begin{array}{l}0.97 \\
(0.18)\end{array}$ & $\begin{array}{l}0.94 \\
(0.24)\end{array}$ & $\begin{array}{l}0.97 \\
(0.16)\end{array}$ \\
\hline Pharmaco therapy & $\begin{array}{l}0-1 \text { dummy variable, }=1 \text { if facility } \\
\text { offers pharmaco therapy }\end{array}$ & $\begin{array}{c}0.41 \\
(0.49)\end{array}$ & $\begin{array}{c}0.24 \\
(0.42)\end{array}$ & $\begin{array}{c}0.42 \\
(0.49)\end{array}$ & $\begin{array}{l}0.27 \\
(0.45)\end{array}$ & $\begin{array}{l}0.51 \\
(0.50)\end{array}$ & $\begin{array}{l}0.50 \\
(0.50)\end{array}$ & $\begin{array}{l}0.63 \\
(0.48)\end{array}$ \\
\hline Relapse prevention groups & $\begin{array}{l}0-1 \text { dummy variable, }=1 \text { if facility } \\
\text { offers relapse prevention groups }\end{array}$ & $\begin{array}{l}0.78 \\
(0.42)\end{array}$ & $\begin{array}{l}0.65 \\
(0.48)\end{array}$ & $\begin{array}{l}0.76 \\
(0.43)\end{array}$ & $\begin{array}{l}0.79 \\
(0.41)\end{array}$ & $\begin{array}{l}0.82 \\
(0.39)\end{array}$ & $\begin{array}{l}0.77 \\
(0.42)\end{array}$ & $\begin{array}{l}0.81 \\
(0.39)\end{array}$ \\
\hline Aftercare counseling & $\begin{array}{l}0-1 \text { dummy variable, }=1 \text { if facility } \\
\text { offers aftercare counseling }\end{array}$ & $\begin{array}{c}0.78 \\
(0.41)\end{array}$ & $\begin{array}{c}0.72 \\
(0.45)\end{array}$ & $\begin{array}{l}0.86 \\
(0.35)\end{array}$ & $\begin{array}{l}0.71 \\
(0.45)\end{array}$ & $\begin{array}{c}0.83 \\
(0.38)\end{array}$ & $\begin{array}{l}0.70 \\
(0.46)\end{array}$ & $\begin{array}{l}0.83 \\
(0.38)\end{array}$ \\
\hline \multicolumn{9}{|l|}{ Medical Testing } \\
\hline Blood alcohol test & $\begin{array}{l}0-1 \text { dummy variable, }=1 \text { if facility } \\
\text { offers blood alcohol testing }\end{array}$ & $\begin{array}{c}0.45 \\
(0.50)\end{array}$ & $\begin{array}{c}0.38 \\
(0.49)\end{array}$ & $\begin{array}{l}0.46 \\
(0.50)\end{array}$ & $\begin{array}{c}0.38 \\
(0.49)\end{array}$ & $\begin{array}{c}0.50 \\
(0.50)\end{array}$ & $\begin{array}{c}0.47 \\
(0.50)\end{array}$ & $\begin{array}{c}0.57 \\
(0.50)\end{array}$ \\
\hline Drug/alcohol urine screen & $\begin{array}{l}0-1 \text { dummy variable, }=1 \text { if facility } \\
\text { offers drug/alcohol urine screening }\end{array}$ & $\begin{array}{l}0.79 \\
(0.40)\end{array}$ & $\begin{array}{c}0.72 \\
(0.45)\end{array}$ & $\begin{array}{l}0.78 \\
(0.41)\end{array}$ & $\begin{array}{l}0.79 \\
(0.41)\end{array}$ & $\begin{array}{l}0.83 \\
(0.37)\end{array}$ & $\begin{array}{l}0.79 \\
(0.41)\end{array}$ & $\begin{array}{l}0.80 \\
(0.40)\end{array}$ \\
\hline Hepatitis & $\begin{array}{l}0-1 \text { dummy variable, }=1 \text { if facility } \\
\text { offers hepatitis testing }\end{array}$ & $\begin{array}{c}0.24 \\
(0.42)\end{array}$ & $\begin{array}{l}0.17 \\
(0.37)\end{array}$ & $\begin{array}{l}0.21 \\
(0.41)\end{array}$ & $\begin{array}{l}0.21 \\
(0.41)\end{array}$ & $\begin{array}{l}0.27 \\
(0.44)\end{array}$ & $\begin{array}{l}0.29 \\
(0.46)\end{array}$ & $\begin{array}{l}0.32 \\
(0.47)\end{array}$ \\
\hline HIV test & $\begin{array}{l}0-1 \text { dummy variable, }=1 \text { if facility } \\
\text { offers HIV testing }\end{array}$ & $\begin{array}{l}0.32 \\
(0.47)\end{array}$ & $\begin{array}{c}0.17 \\
(0.37)\end{array}$ & $\begin{array}{l}0.22 \\
(0.41)\end{array}$ & $\begin{array}{l}0.35 \\
(0.48)\end{array}$ & $\begin{array}{l}0.36 \\
(0.48)\end{array}$ & $\begin{array}{c}0.44 \\
(0.50)\end{array}$ & $\begin{array}{l}0.38 \\
(0.49)\end{array}$ \\
\hline STD test & $\begin{array}{l}0-1 \text { dummy variable, }=1 \text { if facility } \\
\text { offers STD testing }\end{array}$ & $\begin{array}{c}0.23 \\
(0.42)\end{array}$ & $\begin{array}{l}0.17 \\
(0.38)\end{array}$ & $\begin{array}{l}0.20 \\
(0.40)\end{array}$ & $\begin{array}{l}0.21 \\
(0.41)\end{array}$ & $\begin{array}{l}0.25 \\
(0.43)\end{array}$ & $\begin{array}{l}0.31 \\
(0.46)\end{array}$ & $\begin{array}{l}0.32 \\
(0.47)\end{array}$ \\
\hline TB screen & $\begin{array}{l}0-1 \text { dummy variable, }=1 \text { if facility } \\
\text { offers TB screening }\end{array}$ & $\begin{array}{l}0.36 \\
(0.48)\end{array}$ & $\begin{array}{l}0.25 \\
(0.43)\end{array}$ & $\begin{array}{l}0.30 \\
(0.46)\end{array}$ & $\begin{array}{l}0.36 \\
(0.48)\end{array}$ & $\begin{array}{l}0.39 \\
(0.49)\end{array}$ & $\begin{array}{l}0.53 \\
(0.50)\end{array}$ & $\begin{array}{l}0.47 \\
(0.50)\end{array}$ \\
\hline
\end{tabular}




\begin{tabular}{|c|c|c|c|c|c|c|c|c|}
\hline \multirow[b]{3}{*}{ Variable Name } & \multirow[b]{3}{*}{ Definition } & \multirow{3}{*}{$\begin{array}{c}\begin{array}{c}\text { Full } \\
\text { Sample }\end{array} \\
\mathrm{N}=10,513\end{array}$} & \multicolumn{6}{|c|}{ Ownership Type } \\
\hline & & & \multicolumn{2}{|c|}{ For Profit } & \multicolumn{2}{|c|}{ Not for Profit } & \multicolumn{2}{|c|}{ Public } \\
\hline & & & $\begin{array}{c}\mathrm{MC}=0 \\
\mathrm{~N}=1,283\end{array}$ & $\begin{array}{c}\mathrm{MC}=1 \\
\mathrm{~N}=1,630\end{array}$ & $\begin{array}{c}\mathrm{MC}=0 \\
\mathrm{~N}=2,753\end{array}$ & $\begin{array}{c}\mathrm{MC}=1 \\
\mathrm{~N}=3,694\end{array}$ & $\begin{array}{l}\mathrm{MC}=0 \\
\mathrm{~N}=645\end{array}$ & $\begin{array}{l}\mathrm{MC}=1 \\
\mathrm{~N}=508\end{array}$ \\
\hline \multicolumn{9}{|l|}{ Transitional } \\
\hline Asst obtaining social srvcs & $\begin{array}{l}0-1 \text { dummy variable, }=1 \text { if facility } \\
\text { offers assistance obtaining social } \\
\text { services }\end{array}$ & $\begin{array}{c}0.51 \\
(0.50)\end{array}$ & $\begin{array}{c}0.25 \\
(0.43)\end{array}$ & $\begin{array}{c}0.34 \\
(0.47)\end{array}$ & $\begin{array}{c}0.58 \\
(0.49)\end{array}$ & $\begin{array}{c}0.60 \\
(0.49)\end{array}$ & $\begin{array}{c}0.56 \\
(0.50)\end{array}$ & $\begin{array}{c}0.69 \\
(0.46)\end{array}$ \\
\hline Discharge planning & $\begin{array}{l}0-1 \text { dummy variable, }=1 \text { if facility } \\
\text { offers discharge planning }\end{array}$ & $\begin{array}{c}0.82 \\
(0.39)\end{array}$ & $\begin{array}{c}0.66 \\
(0.47)\end{array}$ & $\begin{array}{c}0.78 \\
(0.41)\end{array}$ & $\begin{array}{c}0.82 \\
(0.39)\end{array}$ & $\begin{array}{c}0.87 \\
(0.33)\end{array}$ & $\begin{array}{c}0.83 \\
(0.38)\end{array}$ & $\begin{array}{c}0.88 \\
(0.32)\end{array}$ \\
\hline Employment training & $\begin{array}{l}0-1 \text { dummy variable, }=1 \text { if facility } \\
\text { offers employment training }\end{array}$ & $\begin{array}{c}0.36 \\
(0.48)\end{array}$ & $\begin{array}{c}0.22 \\
(0.42)\end{array}$ & $\begin{array}{c}0.23 \\
(0.42)\end{array}$ & $\begin{array}{c}0.48 \\
(0.50)\end{array}$ & $\begin{array}{c}0.36 \\
(0.48)\end{array}$ & $\begin{array}{c}0.41 \\
(0.49)\end{array}$ & $\begin{array}{c}0.40 \\
(0.49)\end{array}$ \\
\hline Housing assistance & $\begin{array}{l}0-1 \text { dummy variable, }=1 \text { if facility } \\
\text { offers housing assistance }\end{array}$ & $\begin{array}{c}0.30 \\
(0.46)\end{array}$ & $\begin{array}{c}0.12 \\
(0.32)\end{array}$ & $\begin{array}{c}0.17 \\
(0.37)\end{array}$ & $\begin{array}{c}0.40 \\
(0.49)\end{array}$ & $\begin{array}{c}0.34 \\
(0.47)\end{array}$ & $\begin{array}{c}0.32 \\
(0.47)\end{array}$ & $\begin{array}{c}0.37 \\
(0.48)\end{array}$ \\
\hline Referral to other trans srvcs & $\begin{array}{l}0-1 \text { dummy variable, }=1 \text { if facility } \\
\text { offers referrals to other transitional } \\
\text { services }\end{array}$ & $\begin{array}{c}0.84 \\
(0.37)\end{array}$ & $\begin{array}{c}0.69 \\
(0.46)\end{array}$ & $\begin{array}{c}0.81 \\
(0.39)\end{array}$ & $\begin{array}{c}0.86 \\
(0.35)\end{array}$ & $\begin{array}{c}0.88 \\
(0.33)\end{array}$ & $\begin{array}{c}0.86 \\
(0.34)\end{array}$ & $\begin{array}{c}0.88 \\
(0.33)\end{array}$ \\
\hline \multicolumn{9}{|l|}{ Other services } \\
\hline Case management & $\begin{array}{l}0-1 \text { dummy variable, }=1 \text { if facility } \\
\text { offers case management }\end{array}$ & $\begin{array}{c}0.66 \\
(0.47)\end{array}$ & $\begin{array}{c}0.49 \\
(0.50)\end{array}$ & $\begin{array}{c}0.56 \\
(0.50)\end{array}$ & $\begin{array}{c}0.71 \\
(0.46)\end{array}$ & $\begin{array}{c}0.71 \\
(0.46)\end{array}$ & $\begin{array}{c}0.71 \\
(0.45)\end{array}$ & $\begin{array}{c}0.78 \\
(0.42)\end{array}$ \\
\hline Child care & $\begin{array}{l}0-1 \text { dummy variable, }=1 \text { if facility } \\
\text { offers child care }\end{array}$ & $\begin{array}{c}0.10 \\
(0.30)\end{array}$ & $\begin{array}{c}0.01 \\
(0.11)\end{array}$ & $\begin{array}{c}0.03 \\
(0.17)\end{array}$ & $\begin{array}{c}0.13 \\
(0.34)\end{array}$ & $\begin{array}{c}0.13 \\
(0.33)\end{array}$ & $\begin{array}{c}0.13 \\
(0.34)\end{array}$ & $\begin{array}{c}0.11 \\
(0.31)\end{array}$ \\
\hline Domestic violence & $\begin{array}{l}0-1 \text { dummy variable, }=1 \text { if facility } \\
\text { offers domestic violence }\end{array}$ & $\begin{array}{c}0.34 \\
(0.47)\end{array}$ & $\begin{array}{c}0.34 \\
(0.47)\end{array}$ & $\begin{array}{c}0.38 \\
(0.49)\end{array}$ & $\begin{array}{c}0.31 \\
(0.46)\end{array}$ & $\begin{array}{c}0.35 \\
(0.48)\end{array}$ & $\begin{array}{c}0.27 \\
(0.45)\end{array}$ & $\begin{array}{c}0.34 \\
(0.47)\end{array}$ \\
\hline HIV/AIDS education & $\begin{array}{l}0-1 \text { dummy variable, }=1 \text { if facility } \\
\text { offers HIV/AIDS education }\end{array}$ & $\begin{array}{c}0.55 \\
(0.50)\end{array}$ & $\begin{array}{c}0.40 \\
(0.49)\end{array}$ & $\begin{array}{c}0.43 \\
(0.50)\end{array}$ & $\begin{array}{c}0.61 \\
(0.49)\end{array}$ & $\begin{array}{c}0.58 \\
(0.49)\end{array}$ & $\begin{array}{c}0.65 \\
(0.48)\end{array}$ & $\begin{array}{c}0.59 \\
(0.49)\end{array}$ \\
\hline Outcome follow-up & $\begin{array}{l}0-1 \text { dummy variable, }=1 \text { if facility } \\
\text { offers outcome follow-up }\end{array}$ & $\begin{array}{c}0.49 \\
(0.50)\end{array}$ & $\begin{array}{c}0.35 \\
(0.48)\end{array}$ & $\begin{array}{c}0.45 \\
(0.50)\end{array}$ & $\begin{array}{c}0.52 \\
(0.50)\end{array}$ & $\begin{array}{c}0.55 \\
(0.50)\end{array}$ & $\begin{array}{c}0.48 \\
(0.50)\end{array}$ & $\begin{array}{c}0.49 \\
(0.50)\end{array}$ \\
\hline Transportation assist & $\begin{array}{l}0-1 \text { dummy variable, }=1 \text { if facility } \\
\text { offers transportation assistance }\end{array}$ & $\begin{array}{c}0.35 \\
(0 . .48)\end{array}$ & $\begin{array}{c}0.10 \\
(0.30)\end{array}$ & $\begin{array}{c}0.23 \\
(0.42)\end{array}$ & $\begin{array}{c}0.42 \\
(0.49)\end{array}$ & $\begin{array}{c}0.40 \\
(0.49)\end{array}$ & $\begin{array}{c}0.44 \\
(0.50)\end{array}$ & $\begin{array}{c}0.47 \\
(0.50)\end{array}$ \\
\hline Acupuncture & $\begin{array}{l}0-1 \text { dummy variable, }=1 \text { if facility } \\
\text { offers acupuncture }\end{array}$ & $\begin{array}{c}0.05 \\
(0.23)\end{array}$ & $\begin{array}{c}0.03 \\
(0.16)\end{array}$ & $\begin{array}{c}0.04 \\
(0.21)\end{array}$ & $\begin{array}{c}0.06 \\
(0.23)\end{array}$ & $\begin{array}{c}0.06 \\
(0.23)\end{array}$ & $\begin{array}{l}0.07 \\
(0.25)\end{array}$ & $\begin{array}{c}0.10 \\
(0.30)\end{array}$ \\
\hline
\end{tabular}




\begin{tabular}{|c|c|c|c|c|c|c|c|c|}
\hline \multirow[b]{3}{*}{ Variable Name } & \multirow[b]{3}{*}{ Definition } & \multirow{3}{*}{$\begin{array}{c}\text { Full } \\
\text { Sample } \\
\mathrm{N}=10,513\end{array}$} & \multicolumn{6}{|c|}{ Ownership Type } \\
\hline & & & \multicolumn{2}{|c|}{ For Profit } & \multicolumn{2}{|c|}{ Not for Profit } & \multicolumn{2}{|c|}{ Public } \\
\hline & & & $\begin{array}{c}\mathrm{MC}=0 \\
\mathrm{~N}=1,283\end{array}$ & $\begin{array}{c}\mathrm{MC}=1 \\
\mathrm{~N}=1,630\end{array}$ & $\begin{array}{c}\mathrm{MC}=0 \\
\mathrm{~N}=2,753\end{array}$ & $\begin{array}{c}\mathrm{MC}=1 \\
\mathrm{~N}=3,694\end{array}$ & $\begin{array}{l}\mathrm{MC}=0 \\
\mathrm{~N}=645\end{array}$ & $\begin{array}{l}\mathrm{MC}=1 \\
\mathrm{~N}=508\end{array}$ \\
\hline MC & $\begin{array}{l}0-1 \text { dummy variable, }=1 \text { if facility has } \\
\text { agreements or contracts with managed } \\
\text { care organizations to provide substance } \\
\text { abuse treatment services }\end{array}$ & $\begin{array}{c}0.55 \\
(0.50)\end{array}$ & 0 & 1 & 0 & 1 & 0 & 1 \\
\hline Focus: substance abuse & $\begin{array}{l}0-1 \text { dummy variable, }=1 \text { if primary focus of } \\
\text { facility is substance abuse treatment } \\
\text { services }\end{array}$ & $\begin{array}{c}0.62 \\
(0.48)\end{array}$ & $\begin{array}{c}0.73 \\
(0.44)\end{array}$ & $\begin{array}{c}0.55 \\
(0.50)\end{array}$ & $\begin{array}{c}0.70 \\
(0.46)\end{array}$ & $\begin{array}{c}0.58 \\
(0.49)\end{array}$ & $\begin{array}{l}0.58 \\
(0.49)\end{array}$ & $\begin{array}{c}0.49 \\
(0.50)\end{array}$ \\
\hline Focus: mental health & $\begin{array}{l}0-1 \text { dummy variable, }=1 \text { if primary focus of } \\
\text { facility is mental health services }\end{array}$ & $\begin{array}{c}0.09 \\
(0.29)\end{array}$ & $\begin{array}{c}0.06 \\
(0.24)\end{array}$ & $\begin{array}{c}0.12 \\
(0.32)\end{array}$ & $\begin{array}{c}0.08 \\
(0.27)\end{array}$ & $\begin{array}{c}0.09 \\
(0.29)\end{array}$ & $\begin{array}{c}0.10 \\
(0.31)\end{array}$ & $\begin{array}{c}0.10 \\
(0.30)\end{array}$ \\
\hline Focus: general health & $\begin{array}{l}0-1 \text { dummy variable, }=1 \text { if primary focus of } \\
\text { facility is general health care }\end{array}$ & $\begin{array}{c}0.02 \\
(0.13)\end{array}$ & $\begin{array}{c}0.00 \\
(0.06)\end{array}$ & $\begin{array}{l}0.01 \\
(0.10)\end{array}$ & $\begin{array}{l}0.01 \\
(0.11)\end{array}$ & $\begin{array}{c}0.03 \\
(0.18)\end{array}$ & $\begin{array}{l}0.01 \\
(0.10)\end{array}$ & $\begin{array}{c}0.02 \\
(0.13)\end{array}$ \\
\hline $\begin{array}{l}\text { Focus: mental health \& } \\
\text { substance abuse }\end{array}$ & $\begin{array}{l}0-1 \text { dummy variable, }=1 \text { if focus of facility } \\
\text { is a mix of mental health and substance } \\
\text { abuse treatment services }\end{array}$ & $\begin{array}{c}0.24 \\
(0.43)\end{array}$ & $\begin{array}{c}0.17 \\
(0.38)\end{array}$ & $\begin{array}{c}0.31 \\
(0.46)\end{array}$ & $\begin{array}{l}0.16 \\
(0.37)\end{array}$ & $\begin{array}{c}0.28 \\
(0.45)\end{array}$ & $\begin{array}{l}0.27 \\
(0.44)\end{array}$ & $\begin{array}{c}0.37 \\
(0.48)\end{array}$ \\
\hline Focus: other & $\begin{array}{l}0-1 \text { dummy variable, }=1 \text { if primary focus of } \\
\text { facility is "other" }\end{array}$ & $\begin{array}{c}0.02 \\
(0.16)\end{array}$ & $\begin{array}{c}0.03 \\
(0.16)\end{array}$ & $\begin{array}{l}0.01 \\
(0.08)\end{array}$ & $\begin{array}{c}0.04 \\
(0.20)\end{array}$ & $\begin{array}{c}0.02 \\
(0.13)\end{array}$ & $\begin{array}{l}0.04 \\
(0.20)\end{array}$ & $\begin{array}{c}0.02 \\
(0.15)\end{array}$ \\
\hline Hospital: general & $\begin{array}{l}0-1 \text { dummy variable, }=1 \text { if facility is located } \\
\text { in, or operated by, a general hospital }\end{array}$ & $\begin{array}{l}0.10 \\
(0.30)\end{array}$ & $\begin{array}{l}0.01 \\
(0.12)\end{array}$ & $\begin{array}{l}0.05 \\
(0.22)\end{array}$ & $\begin{array}{l}0.05 \\
(0.22)\end{array}$ & $\begin{array}{l}0.19 \\
(0.39)\end{array}$ & $\begin{array}{l}0.07 \\
(0.25)\end{array}$ & $\begin{array}{c}0.15 \\
(0.35)\end{array}$ \\
\hline Hospital: psychiatric & $\begin{array}{l}0-1 \text { dummy variable, }=1 \text { if facility is located } \\
\text { in, or operated by, a psychiatric hospital }\end{array}$ & $\begin{array}{c}0.02 \\
(0.15)\end{array}$ & $\begin{array}{c}0.01 \\
(0.08)\end{array}$ & $\begin{array}{c}0.06 \\
(0.23)\end{array}$ & $\begin{array}{c}0.01 \\
(0.07)\end{array}$ & $\begin{array}{c}0.02 \\
(0.15)\end{array}$ & $\begin{array}{c}0.04 \\
(0.20)\end{array}$ & $\begin{array}{c}0.03 \\
(0.17)\end{array}$ \\
\hline Hospital: other specialty & $\begin{array}{l}0-1 \text { dummy variable, }=1 \text { if facility is located } \\
\text { in, or operated by, an "other" specialty } \\
\text { hospital (e.g., alcoholism, maternity, etc.) }\end{array}$ & $\begin{array}{l}0.01 \\
(0.08)\end{array}$ & $\begin{array}{c}0.00 \\
(0.03)\end{array}$ & $\begin{array}{l}0.01 \\
(0.10)\end{array}$ & $\begin{array}{l}0.00 \\
(0.05)\end{array}$ & $\begin{array}{l}0.01 \\
(0.09)\end{array}$ & $\begin{array}{l}0.01 \\
(0.10)\end{array}$ & $\begin{array}{l}0.01 \\
(0.09)\end{array}$ \\
\hline Solo practice & $\begin{array}{l}0-1 \text { dummy variable, }=1 \text { if facility is a } \\
\text { private solo practice }\end{array}$ & $\begin{array}{c}0.05 \\
(0.22)\end{array}$ & $\begin{array}{c}0.26 \\
(0.44)\end{array}$ & $\begin{array}{l}0.13 \\
(0.34)\end{array}$ & $\begin{array}{c}0.00 \\
(0.00)\end{array}$ & $\begin{array}{c}0.00 \\
(0.00)\end{array}$ & $\begin{array}{l}0.00 \\
(0.00)\end{array}$ & $\begin{array}{c}0.00 \\
(0.00)\end{array}$ \\
\hline Halfway house & $\begin{array}{l}0-1 \text { dummy variable, }=1 \text { if facility operates } \\
\text { a halfway house for substance abuse } \\
\text { clients }\end{array}$ & $\begin{array}{l}0.14 \\
(0.35)\end{array}$ & $\begin{array}{l}0.06 \\
(0.24)\end{array}$ & $\begin{array}{c}0.05 \\
(0.23)\end{array}$ & $\begin{array}{c}0.23 \\
(0.42)\end{array}$ & $\begin{array}{c}0.17 \\
(0.38)\end{array}$ & $\begin{array}{l}0.07 \\
(0.26)\end{array}$ & $\begin{array}{c}0.07 \\
(0.26)\end{array}$ \\
\hline Any hospital inpatient & $\begin{array}{l}0-1 \text { dummy variable, }=1 \text { if facility offers } \\
\text { hospital inpatient substance abuse } \\
\text { services }\end{array}$ & $\begin{array}{c}0.07 \\
(0.25)\end{array}$ & $\begin{array}{c}0.01 \\
(0.12)\end{array}$ & $\begin{array}{c}0.09 \\
(0.29)\end{array}$ & $\begin{array}{c}0.02 \\
(0.15)\end{array}$ & $\begin{array}{c}0.11 \\
(0.31)\end{array}$ & $\begin{array}{c}0.06 \\
(0.24)\end{array}$ & $\begin{array}{c}0.10 \\
(0.30)\end{array}$ \\
\hline Any non-hospital residential & $\begin{array}{l}0-1 \text { dummy variable, }=1 \text { if facility offers } \\
\text { non-hospital residential substance abuse } \\
\text { services }\end{array}$ & $\begin{array}{c}0.27 \\
(0.44)\end{array}$ & $\begin{array}{c}0.11 \\
(0.31)\end{array}$ & $\begin{array}{c}0.15 \\
(0.36)\end{array}$ & $\begin{array}{l}0.46 \\
(0.50)\end{array}$ & $\begin{array}{l}0.26 \\
(0.44)\end{array}$ & $\begin{array}{l}0.25 \\
(0.43)\end{array}$ & $\begin{array}{c}0.18 \\
(0.39)\end{array}$ \\
\hline Any outpatient & $\begin{array}{l}0-1 \text { dummy variable, }=1 \text { if facility offers } \\
\text { outpatient substance abuse services }\end{array}$ & $\begin{array}{c}0.83 \\
(0.38)\end{array}$ & $\begin{array}{c}0.94 \\
(0.24)\end{array}$ & $\begin{array}{c}0.92 \\
(0.27)\end{array}$ & $\begin{array}{c}0.67 \\
(0.47)\end{array}$ & $\begin{array}{c}0.86 \\
(0.35)\end{array}$ & $\begin{array}{l}0.81 \\
(0.39)\end{array}$ & $\begin{array}{c}0.88 \\
(0.32)\end{array}$ \\
\hline Methadone/LAAM & $\begin{array}{l}0-1 \text { dummy variable },=1 \text { if facility } \\
\text { dispenses methadone or LAAM }\end{array}$ & $\begin{array}{c}0.09 \\
(0.29)\end{array}$ & $\begin{array}{c}0.18 \\
(0.39)\end{array}$ & $\begin{array}{l}0.09 \\
(0.29)\end{array}$ & $\begin{array}{c}0.06 \\
(0.25)\end{array}$ & $\begin{array}{c}0.08 \\
(0.26)\end{array}$ & $\begin{array}{l}0.11 \\
(0.31)\end{array}$ & $\begin{array}{c}0.09 \\
(0.29)\end{array}$ \\
\hline
\end{tabular}


Table 2 (continued): Summary Statistics of Regressors ${ }^{1}$

\begin{tabular}{|c|c|c|c|c|c|c|c|c|}
\hline \multirow[b]{3}{*}{ Variable Name } & \multirow[b]{3}{*}{ Definition } & \multirow{3}{*}{$\begin{array}{c}\begin{array}{c}\text { Full } \\
\text { Sample }\end{array} \\
\mathrm{N}=10,513\end{array}$} & \multicolumn{6}{|c|}{ Ownership Type } \\
\hline & & & \multicolumn{2}{|c|}{ For Profit } & \multicolumn{2}{|c|}{ Not for Profit } & \multicolumn{2}{|c|}{ Public } \\
\hline & & & $\begin{array}{c}\mathrm{MC}=0 \\
\mathrm{~N}=1,283\end{array}$ & $\begin{array}{c}\mathrm{MC}=1 \\
\mathrm{~N}=1,630\end{array}$ & $\begin{array}{c}\mathrm{MC}=0 \\
\mathrm{~N}=2,753\end{array}$ & $\begin{array}{c}\mathrm{MC}=1 \\
\mathrm{~N}=3,694\end{array}$ & $\begin{array}{l}\mathrm{MC}=0 \\
\mathrm{~N}=645\end{array}$ & $\begin{array}{l}\mathrm{MC}=1 \\
\mathrm{~N}=508\end{array}$ \\
\hline Accredited & $\begin{array}{l}0-1 \text { dummy variable, }=1 \text { if facility is } \\
\text { accredited by JCAHO or CARF or NCQA }\end{array}$ & $\begin{array}{c}0.33 \\
(0.47)\end{array}$ & $\begin{array}{c}0.09 \\
(0.29)\end{array}$ & $\begin{array}{c}0.34 \\
(0.47)\end{array}$ & $\begin{array}{c}0.21 \\
(0.41)\end{array}$ & $\begin{array}{c}0.49 \\
(0.50)\end{array}$ & $\begin{array}{c}0.29 \\
(0.45)\end{array}$ & $\begin{array}{c}0.36 \\
(0.48)\end{array}$ \\
\hline Licensed by state & $\begin{array}{l}0-1 \text { dummy variable },=1 \text { if facility is } \\
\text { licensed by a state substance abuse } \\
\text { agency }\end{array}$ & $\begin{array}{c}0.90 \\
(0.30)\end{array}$ & $\begin{array}{c}0.86 \\
(0.35)\end{array}$ & $\begin{array}{l}0.85 \\
(0.85)\end{array}$ & $\begin{array}{l}0.88 \\
(0.33)\end{array}$ & $\begin{array}{c}0.95 \\
(0.23)\end{array}$ & $\begin{array}{l}0.90 \\
(0.30)\end{array}$ & $\begin{array}{c}0.94 \\
(0.23)\end{array}$ \\
\hline Admissions (log) & $\begin{array}{l}\text { Size of facility, measured by log of annual } \\
\text { admissions }\end{array}$ & $\begin{array}{c}4.90 \\
(1.28)\end{array}$ & $\begin{array}{c}4.59 \\
(1.25)\end{array}$ & $\begin{array}{c}4.83 \\
(1.30)\end{array}$ & $\begin{array}{c}4.67 \\
(1.26)\end{array}$ & $\begin{array}{c}5.17 \\
(1.24)\end{array}$ & $\begin{array}{c}4.95 \\
(1.28)\end{array}$ & $\begin{array}{c}5.24 \\
(1.10)\end{array}$ \\
\hline $\begin{array}{l}\text { Accepts cash or self- } \\
\text { payment }\end{array}$ & $\begin{array}{l}0-1 \text { dummy variable, }=1 \text { if facility accepts } \\
\text { cash or self-payment for substance abuse } \\
\text { treatment }\end{array}$ & $\begin{array}{c}0.93 \\
(0.26)\end{array}$ & $\begin{array}{l}0.97 \\
(0.16)\end{array}$ & $\begin{array}{c}0.99 \\
(0.09)\end{array}$ & $\begin{array}{c}0.82 \\
(0.38)\end{array}$ & $\begin{array}{l}0.97 \\
(0.17)\end{array}$ & $\begin{array}{l}0.87 \\
(0.34)\end{array}$ & $\begin{array}{l}0.97 \\
(0.16)\end{array}$ \\
\hline $\begin{array}{l}\text { Accepts private health } \\
\text { insurance }\end{array}$ & $\begin{array}{l}0-1 \text { dummy variable, }=1 \text { if facility accepts } \\
\text { private health insurance for substance } \\
\text { abuse treatment }\end{array}$ & $\begin{array}{c}0.71 \\
(0.45)\end{array}$ & $\begin{array}{l}0.47 \\
(0.50)\end{array}$ & $\begin{array}{c}0.93 \\
(0.25)\end{array}$ & $\begin{array}{c}0.44 \\
(0.50)\end{array}$ & $\begin{array}{c}0.89 \\
(0.31)\end{array}$ & $\begin{array}{l}0.63 \\
(0.48)\end{array}$ & $\begin{array}{c}0.91 \\
(0.29)\end{array}$ \\
\hline Accepts Medicaid & $\begin{array}{l}0-1 \text { dummy variable },=1 \text { if facility accepts } \\
\text { Medicaid for substance abuse treatment }\end{array}$ & $\begin{array}{c}0.54 \\
(0.50)\end{array}$ & $\begin{array}{c}0.17 \\
(0.37)\end{array}$ & $\begin{array}{l}0.46 \\
(0.50)\end{array}$ & $\begin{array}{c}0.40 \\
(0.49)\end{array}$ & $\begin{array}{c}0.75 \\
(0.43)\end{array}$ & $\begin{array}{c}0.59 \\
(0.49)\end{array}$ & $\begin{array}{c}0.86 \\
(0.35)\end{array}$ \\
\hline Accepts Medicare & $\begin{array}{l}0-1 \text { dummy variable, }=1 \text { if facility accepts } \\
\text { Medicare for substance abuse treatment }\end{array}$ & $\begin{array}{c}0.36 \\
(0.48)\end{array}$ & $\begin{array}{c}0.13 \\
(0.33)\end{array}$ & $\begin{array}{l}0.38 \\
(0.48)\end{array}$ & $\begin{array}{c}0.21 \\
(0.41)\end{array}$ & $\begin{array}{c}0.52 \\
(0.50)\end{array}$ & $\begin{array}{l}0.39 \\
(0.49)\end{array}$ & $\begin{array}{c}0.60 \\
(0.49)\end{array}$ \\
\hline $\begin{array}{l}\text { Accepts state-financed } \\
\text { health insurance }\end{array}$ & $\begin{array}{l}0-1 \text { dummy variable, }=1 \text { if facility accepts } \\
\text { state-financed health insurance for } \\
\text { substance abuse treatment }\end{array}$ & $\begin{array}{l}0.37 \\
(0.48)\end{array}$ & $\begin{array}{l}0.10 \\
(0.31)\end{array}$ & $\begin{array}{l}0.37 \\
(0.48)\end{array}$ & $\begin{array}{c}0.22 \\
(0.42)\end{array}$ & $\begin{array}{c}0.54 \\
(0.50)\end{array}$ & $\begin{array}{l}0.36 \\
(0.48)\end{array}$ & $\begin{array}{c}0.66 \\
(0.48)\end{array}$ \\
\hline $\begin{array}{l}\text { Receives public funds (not } \\
\text { Medicare, Medicaid) }\end{array}$ & $\begin{array}{l}0-1 \text { dummy variable, }=1 \text { if facility receives } \\
\text { public funds (not Medicare or Medicaid) for } \\
\text { substance abuse treatment }\end{array}$ & $\begin{array}{c}0.66 \\
(0.47)\end{array}$ & $\begin{array}{l}0.25 \\
(0.43)\end{array}$ & $\begin{array}{c}0.26 \\
(0.44)\end{array}$ & $\begin{array}{c}0.79 \\
(0.41)\end{array}$ & $\begin{array}{c}0.79 \\
(0.41)\end{array}$ & $\begin{array}{c}0.93 \\
(0.25)\end{array}$ & $\begin{array}{c}0.90 \\
(0.30)\end{array}$ \\
\hline Offers payment assistance & $\begin{array}{l}0-1 \text { dummy variable, }=1 \text { if facility offers } \\
\text { payment assistance for clients receiving } \\
\text { substance abuse treatment }\end{array}$ & $\begin{array}{c}0.79 \\
(0.40)\end{array}$ & $\begin{array}{l}0.66 \\
(0.47)\end{array}$ & $\begin{array}{c}0.71 \\
(0.45)\end{array}$ & $\begin{array}{c}0.74 \\
(0.44)\end{array}$ & $\begin{array}{c}0.88 \\
(0.32)\end{array}$ & $\begin{array}{l}0.84 \\
(0.37)\end{array}$ & $\begin{array}{c}0.93 \\
(0.26)\end{array}$ \\
\hline Metropolitan area & $\begin{array}{l}0-1 \text { dummy variable, }=1 \text { if facility is located } \\
\text { within a metropolitan area }\end{array}$ & $\begin{array}{c}0.77 \\
(0.42)\end{array}$ & $\begin{array}{c}0.85 \\
(0.35)\end{array}$ & $\begin{array}{c}0.84 \\
(0.36)\end{array}$ & $\begin{array}{c}0.81 \\
(0.39)\end{array}$ & $\begin{array}{c}0.74 \\
(0.44)\end{array}$ & $\begin{array}{c}0.63 \\
(0.48)\end{array}$ & $\begin{array}{c}0.51 \\
(0.50)\end{array}$ \\
\hline $\begin{array}{l}\text { Population density - } \\
\text { county (log) }\end{array}$ & $\begin{array}{l}\text { Log of the number of people in the county } \\
\text { per square mile }\end{array}$ & $\begin{array}{c}6.07 \\
(1.92)\end{array}$ & $\begin{array}{c}6.13 \\
(1.58)\end{array}$ & $\begin{array}{c}6.27 \\
(1.68)\end{array}$ & $\begin{array}{c}6.36 \\
(2.04)\end{array}$ & $\begin{array}{c}6.00 \\
(1.92)\end{array}$ & $\begin{array}{l}5.45 \\
(2.13)\end{array}$ & $\begin{array}{c}5.07 \\
(1.92)\end{array}$ \\
\hline Population - county (log) & Log of the county population & $\begin{array}{l}12.61 \\
(1.63)\end{array}$ & $\begin{array}{l}12.82 \\
(1.49)\end{array}$ & $\begin{array}{l}12.82 \\
(1.39)\end{array}$ & $\begin{array}{l}12.93 \\
(1.67)\end{array}$ & $\begin{array}{l}12.47 \\
(1.63)\end{array}$ & $\begin{array}{l}11.93 \\
(1.69)\end{array}$ & $\begin{array}{l}11.49 \\
(1.57)\end{array}$ \\
\hline Competition - county & Herfindahl Index in the county & $\begin{array}{c}0.26 \\
(0.28)\end{array}$ & $\begin{array}{c}0.23 \\
(0.23)\end{array}$ & $\begin{array}{c}0.21 \\
(0.21)\end{array}$ & $\begin{array}{c}0.23 \\
(0.25)\end{array}$ & $\begin{array}{c}0.28 \\
(0.29)\end{array}$ & $\begin{array}{c}0.38 \\
(0.33)\end{array}$ & $\begin{array}{c}0.45 \\
(0.33)\end{array}$ \\
\hline $\begin{array}{l}\text { Medicare MC enrollees - } \\
\text { county (log) }\end{array}$ & $\begin{array}{l}\text { Log of Medicare managed care enrollees } \\
\text { in the county }\end{array}$ & $\begin{array}{c}7.84 \\
(3.27)\end{array}$ & $\begin{array}{c}8.18 \\
(3.01)\end{array}$ & $\begin{array}{c}8.22 \\
(2.88)\end{array}$ & $\begin{array}{c}8.38 \\
(3.26)\end{array}$ & $\begin{array}{l}7.72 \\
(3.25)\end{array}$ & $\begin{array}{l}6.35 \\
(3.47)\end{array}$ & $\begin{array}{c}5.57 \\
(3.41)\end{array}$ \\
\hline $\begin{array}{l}\text { HMO enrollees - } \\
\text { county (log) }\end{array}$ & Log of HMO enrollees in the county & $\begin{array}{l}10.70 \\
(3.07)\end{array}$ & $\begin{array}{l}11.03 \\
(2.75) \\
\end{array}$ & $\begin{array}{l}11.15 \\
(2.46) \\
\end{array}$ & $\begin{array}{l}11.08 \\
(3.19)\end{array}$ & $\begin{array}{l}10.60 \\
(2.98) \\
\end{array}$ & $\begin{array}{c}9.31 \\
(3.69)\end{array}$ & $\begin{array}{c}8.83 \\
(3.51) \\
\end{array}$ \\
\hline
\end{tabular}


Table 3: Total Services - Structural Equation Results

\begin{tabular}{|c|c|c|c|c|c|c|}
\hline \multirow[b]{2}{*}{ Variable Name } & \multicolumn{2}{|c|}{$\begin{array}{c}\text { For Profit } \\
\mathrm{N}=2,913\end{array}$} & \multicolumn{2}{|c|}{$\begin{array}{c}\text { Not for Profit } \\
\quad \mathrm{N}=6,447\end{array}$} & \multicolumn{2}{|c|}{$\begin{array}{c}\text { Public } \\
\mathrm{N}=1,153\end{array}$} \\
\hline & Coef & P_value & Coef & P_value & Coef & P_value \\
\hline Managed care & 3.818 & 0.000 & -0.889 & 0.348 & -3.725 & 0.001 \\
\hline Focus: substance abuse ${ }^{\dagger}$ & -0.351 & 0.666 & 0.587 & 0.087 & -0.023 & 0.976 \\
\hline Focus: mental health ${ }^{\dagger}$ & -0.976 & 0.280 & 0.328 & 0.391 & -0.495 & 0.577 \\
\hline Focus: general health ${ }^{\dagger}$ & 0.246 & 0.830 & 2.436 & 0.000 & 2.801 & 0.011 \\
\hline Focus: mental \& substance ${ }^{\dagger}$ & 0.173 & 0.835 & 1.394 & 0.000 & 0.969 & 0.241 \\
\hline Hospital: general $\left.\right|^{\ddagger}$ & 1.271 & 0.019 & -0.020 & 0.946 & 1.074 & 0.059 \\
\hline Hospital: psychiatric ${ }^{\ddagger}$ & 1.729 & 0.009 & 0.941 & 0.022 & 2.317 & 0.007 \\
\hline Hospital: other specialty ${ }^{\ddagger}$ & -1.535 & 0.036 & 1.121 & 0.044 & 2.315 & 0.053 \\
\hline Solo practice & -0.526 & 0.013 & $N / A$ & & $\mathrm{~N} / \mathrm{A}$ & \\
\hline Halfway house & 1.074 & 0.017 & 0.063 & 0.758 & 0.357 & 0.511 \\
\hline Any hospital inpatient & 2.450 & 0.000 & 2.622 & 0.000 & 0.833 & 0.229 \\
\hline Any non-hospital residential & 3.361 & 0.000 & 2.960 & 0.000 & 2.240 & 0.000 \\
\hline Any outpatient & 0.610 & 0.161 & 1.034 & 0.000 & 0.060 & 0.911 \\
\hline Methadone/LAAM dispensed & 3.542 & 0.000 & 2.277 & 0.000 & 1.997 & 0.000 \\
\hline Accredited & 0.613 & 0.007 & 0.705 & 0.000 & 0.900 & 0.014 \\
\hline Licensed by state & 1.123 & 0.000 & 0.716 & 0.002 & 1.070 & 0.050 \\
\hline Admissions (log) & 0.346 & 0.000 & 0.326 & 0.000 & 0.525 & 0.000 \\
\hline Accepts cash or self-payment & -0.742 & 0.296 & -0.904 & 0.000 & 0.599 & 0.388 \\
\hline Accepts private health insurance & -0.525 & 0.133 & 0.642 & 0.099 & 2.047 & 0.000 \\
\hline Accepts Medicaid & 0.281 & 0.239 & 0.920 & 0.000 & 0.600 & 0.213 \\
\hline Accepts Medicare & 0.251 & 0.282 & 0.545 & 0.002 & 0.262 & 0.503 \\
\hline Accepts state-financed health insurance & 0.529 & 0.011 & 0.721 & 0.000 & 0.784 & 0.025 \\
\hline Receives public funds (not Medicare, Medicaid) & 0.545 & 0.013 & 1.235 & 0.000 & 0.971 & 0.113 \\
\hline Offers payment assistance & 1.108 & 0.000 & 0.936 & 0.000 & 1.286 & 0.017 \\
\hline Metropolitan area & -0.133 & 0.663 & -0.472 & 0.037 & -0.453 & 0.347 \\
\hline Population density - county (log) & 0.052 & 0.498 & 0.239 & 0.006 & 0.249 & 0.119 \\
\hline Population - county (log) & 0.080 & 0.538 & 0.149 & 0.168 & 0.434 & 0.112 \\
\hline Competition - county & 0.722 & 0.199 & -0.805 & 0.033 & 0.970 & 0.226 \\
\hline Constant & 4.129 & 0.030 & 4.066 & 0.001 & -0.209 & 0.945 \\
\hline F-statistic for instruments (statistic, $p_{-}$value) & 10.88 & 0.004 & 49.49 & 0.000 & 5.35 & 0.069 \\
\hline Test of overidentification (statistic, $\left.p \_v a l u e\right)$ & 1.12 & 0.289 & 2.57 & 0.109 & 0.23 & 0.633 \\
\hline
\end{tabular}


Table 3A: Total Services - Selection Equation Results

\begin{tabular}{|c|c|c|c|c|c|c|}
\hline \multirow[b]{2}{*}{ Variable Name } & \multicolumn{2}{|c|}{$\begin{array}{c}\text { For Profit } \\
\mathrm{N}=2,913\end{array}$} & \multicolumn{2}{|c|}{$\begin{array}{c}\text { Not for Profit } \\
\quad N=6,447\end{array}$} & \multicolumn{2}{|c|}{$\begin{array}{c}\text { Public } \\
\mathrm{N}=1,153\end{array}$} \\
\hline & Coef & P_value & Coef & P_value & Coef & P_value \\
\hline Medicare MC enrollments (log) & 0.049 & 0.015 & 0.066 & 0.000 & 0.016 & 0.533 \\
\hline HMO enrollments (log) & 0.024 & 0.183 & 0.066 & 0.000 & 0.045 & 0.036 \\
\hline Focus: substance abuse ${ }^{\dagger}$ & 0.261 & 0.359 & 0.052 & 0.666 & -0.034 & 0.904 \\
\hline Focus: mental health ${ }^{\dagger}$ & 0.320 & 0.308 & -0.169 & 0.216 & -0.130 & 0.670 \\
\hline Focus: general health ${ }^{\dagger}$ & 0.031 & 0.949 & 0.115 & 0.565 & 0.392 & 0.369 \\
\hline Focus: mental \& substance ${ }^{\dagger}$ & 0.519 & 0.082 & 0.092 & 0.484 & 0.010 & 0.973 \\
\hline Hospital: general ${ }^{\ddagger}$ & -0.070 & 0.754 & 0.340 & 0.004 & 0.432 & 0.028 \\
\hline Hospital: psychiatric ${ }^{\ddagger}$ & -0.023 & 0.933 & 0.332 & 0.048 & -0.380 & 0.176 \\
\hline Hospital: other specialty ${ }^{\ddagger}$ & 0.332 & 0.418 & 0.167 & 0.560 & 0.150 & 0.686 \\
\hline Solo practice & -0.252 & 0.001 & $\mathrm{~N} / \mathrm{A}$ & & N/A & \\
\hline Halfway house & -0.116 & 0.507 & 0.164 & 0.007 & 0.077 & 0.635 \\
\hline Any hospital inpatient & 0.184 & 0.376 & 0.303 & 0.002 & 0.042 & 0.842 \\
\hline Any non-hospital residential & 0.114 & 0.326 & -0.024 & 0.689 & -0.028 & 0.825 \\
\hline Any outpatient & 0.011 & 0.953 & 0.233 & 0.000 & 0.039 & 0.796 \\
\hline Methadone/LAAM dispensed & -0.451 & 0.000 & -0.200 & 0.037 & -0.010 & 0.947 \\
\hline Accredited & 0.486 & 0.000 & 0.287 & 0.000 & -0.032 & 0.766 \\
\hline Licensed by state & 0.177 & 0.034 & 0.284 & 0.001 & 0.224 & 0.221 \\
\hline Admissions (log) & 0.086 & 0.002 & 0.106 & 0.000 & 0.136 & 0.000 \\
\hline Accepts cash or self-payment & 0.153 & 0.551 & 0.222 & 0.022 & 0.058 & 0.797 \\
\hline Accepts private health insurance & 1.326 & 0.000 & 0.915 & 0.000 & 0.473 & 0.002 \\
\hline Accepts Medicaid & 0.395 & 0.000 & 0.303 & 0.000 & 0.509 & 0.000 \\
\hline Accepts Medicare & 0.190 & 0.015 & 0.135 & 0.009 & -0.060 & 0.583 \\
\hline Accepts state-financed health insurance & 0.379 & 0.000 & 0.278 & 0.000 & 0.359 & 0.000 \\
\hline Receives public funds (not Medicare, Medicaid) & -0.015 & 0.847 & 0.043 & 0.556 & -0.353 & 0.044 \\
\hline Offers payment assistance & -0.072 & 0.248 & 0.095 & 0.108 & 0.152 & 0.379 \\
\hline Metropolitan area & -0.304 & 0.005 & -0.052 & 0.544 & -0.106 & 0.487 \\
\hline Population density - county (log) & 0.056 & 0.082 & -0.015 & 0.588 & 0.032 & 0.573 \\
\hline Population - county (log) & -0.141 & 0.041 & -0.226 & 0.000 & -0.216 & 0.034 \\
\hline Competition - county & -0.440 & 0.032 & -0.197 & 0.144 & -0.228 & 0.344 \\
\hline Constant & -0.940 & 0.210 & -0.483 & 0.267 & 0.157 & 0.874 \\
\hline
\end{tabular}


Table 4: Effects of Managed Care on Individual Services ${ }^{\dagger}$

\begin{tabular}{|c|c|c|c|c|c|c|}
\hline & \multicolumn{2}{|c|}{ For Profit } & \multicolumn{2}{|c|}{ Not for Profit } & \multicolumn{2}{|c|}{ Public } \\
\hline & Coef & Marginal* & Coef & Marginal* & Coef & Marginal* \\
\hline \multicolumn{7}{|l|}{ Assessment } \\
\hline Substance abuse assessment & $\begin{array}{c}0.355 \\
(0.440)\end{array}$ & $\begin{array}{c}0.020 \\
(0.480)\end{array}$ & $\begin{array}{c}0.616 \\
(0.001)\end{array}$ & $\begin{array}{c}0.024 \\
(0.036)\end{array}$ & $\begin{array}{c}0.950 \\
(0.039)\end{array}$ & $\begin{array}{c}0.030 \\
(0.299)\end{array}$ \\
\hline Mental health assessment & $\begin{array}{c}0.477 \\
(0.167)\end{array}$ & $\begin{array}{c}0.126 \\
(0.159)\end{array}$ & $\begin{array}{c}0.374 \\
(0.539)\end{array}$ & $\begin{array}{c}0.093 \\
(0.523)\end{array}$ & 0.078 & $\begin{array}{c}0.016 \\
(<0.001)\end{array}$ \\
\hline \multicolumn{7}{|l|}{ Therapy/Counseling } \\
\hline Family counseling & $\begin{array}{c}0.973 \\
(0.275)\end{array}$ & $\begin{array}{c}0.269 \\
(0.319)\end{array}$ & $\begin{array}{c}-0.197 \\
(0.378)\end{array}$ & $\begin{array}{l}-0.048 \\
(0.374)\end{array}$ & $\begin{array}{c}0.606 \\
(0.584)\end{array}$ & $\begin{array}{c}0.161 \\
(0.590)\end{array}$ \\
\hline Group therapy & $\begin{array}{c}0.478 \\
(0.298)\end{array}$ & $\begin{array}{c}0.057 \\
(0.379)\end{array}$ & $\begin{array}{c}0.194 \\
(0.320)\end{array}$ & $\begin{array}{c}0.017 \\
(0.358)\end{array}$ & $\begin{array}{c}0.422 \\
(0.301)\end{array}$ & $\begin{array}{c}0.034 \\
(0.343)\end{array}$ \\
\hline Individual therapy & $\begin{array}{l}-1.258 \\
(0.002)\end{array}$ & $\begin{array}{l}-0.196 \\
(0.055)\end{array}$ & $\begin{array}{l}-0.026 \\
(0.896)\end{array}$ & $\begin{array}{l}-0.001 \\
(0.895)\end{array}$ & $\begin{array}{c}0.562 \\
(0.217)\end{array}$ & $\begin{array}{c}0.039 \\
(0.273)\end{array}$ \\
\hline Pharmaco therapy & $\begin{array}{c}1.098 \\
(<0.001)\end{array}$ & $\begin{array}{c}0.249 \\
(<0.001)\end{array}$ & $\begin{array}{c}0.217 \\
(0.617)\end{array}$ & $\begin{array}{c}0.056 \\
(0.605)\end{array}$ & $\begin{array}{c}-1.012 \\
(0.019)\end{array}$ & $\begin{array}{l}-0.372 \\
(0.012)\end{array}$ \\
\hline Relapse prevention groups & $\begin{array}{c}1.268 \\
(<0.001)\end{array}$ & $\begin{array}{c}0.362 \\
(<0.001)\end{array}$ & $\begin{array}{c}0.490 \\
(0.084)\end{array}$ & $\begin{array}{c}0.140 \\
(0.111)\end{array}$ & $\begin{array}{c}0.044 \\
(0.973)\end{array}$ & $\begin{array}{c}0.015 \\
(0.973)\end{array}$ \\
\hline Aftercare counseling & $\begin{array}{c}0.950 \\
(0.287)\end{array}$ & $\begin{array}{c}0.173 \\
(0.417)\end{array}$ & $\begin{array}{c}-0.352 \\
(0.121)\end{array}$ & $\begin{array}{c}-0.074 \\
(0.118)\end{array}$ & $\begin{array}{c}0.347 \\
(0.636)\end{array}$ & $\begin{array}{c}0.089 \\
(0.630)\end{array}$ \\
\hline \multicolumn{7}{|l|}{ Medical Testing } \\
\hline Blood alcohol test & $\begin{array}{c}0.033 \\
(0.930)\end{array}$ & $\begin{array}{c}0.013 \\
(0.930)\end{array}$ & $\begin{array}{c}0.116 \\
(0.874)\end{array}$ & $\begin{array}{c}0.042 \\
(0.873)\end{array}$ & $\begin{array}{l}-1.228 \\
(0.006)\end{array}$ & $\begin{array}{l}-0.459 \\
(0.002)\end{array}$ \\
\hline Drug/alcohol urine screen & $\begin{array}{c}1.093 \\
(<0.001)\end{array}$ & $\begin{array}{c}0.313 \\
(<0.001)\end{array}$ & $\begin{array}{c}0.452 \\
(0.070)\end{array}$ & $\begin{array}{c}0.120 \\
(0.095)\end{array}$ & $\begin{array}{l}-0.292 \\
(0.803)\end{array}$ & $\begin{array}{l}-0.065 \\
(0.809)\end{array}$ \\
\hline Hepatitis & $\begin{array}{c}0.388 \\
(0.795)\end{array}$ & $\begin{array}{c}0.028 \\
(0.812)\end{array}$ & $\begin{array}{l}-0.381 \\
(0.259)\end{array}$ & $\begin{array}{c}-0.062 \\
.\end{array}$ & $\begin{array}{c}-0.792 \\
(0.068)\end{array}$ & $\begin{array}{c}-0.202 \\
(0.100)\end{array}$ \\
\hline HIV test & -0.062 & $\begin{array}{c}-0.006 \\
(<0.001)\end{array}$ & $\begin{array}{l}-0.539 \\
(0.134)\end{array}$ & $\begin{array}{l}-0.182 \\
(0.150)\end{array}$ & $\begin{array}{c}-1.487 \\
(<0.001)\end{array}$ & $\begin{array}{c}-0.543 \\
(<0.001)\end{array}$ \\
\hline STD test & -0.093 & $\begin{array}{c}-0.005 \\
(<0.001)\end{array}$ & $\begin{array}{c}-0.630 \\
(0.011)\end{array}$ & $\begin{array}{c}-0.122 \\
(0.041)\end{array}$ & $\begin{array}{l}-0.930 \\
(0.227)\end{array}$ & $\begin{array}{c}-0.239 \\
(0.288)\end{array}$ \\
\hline TB screen & $\begin{array}{c}0.826 \\
(0.094)\end{array}$ & $\begin{array}{c}0.107 \\
(0.181)\end{array}$ & $\begin{array}{l}-0.611 \\
(0.063)\end{array}$ & $\begin{array}{l}-0.189 \\
(0.089)\end{array}$ & $\begin{array}{c}-1.533 \\
(<0.001)\end{array}$ & $\begin{array}{c}-0.549 \\
(<0.001)\end{array}$ \\
\hline
\end{tabular}


Table 4 (continued): Effects of Managed Care on Individual Services ${ }^{\dagger}$

\begin{tabular}{|c|c|c|c|c|c|c|}
\hline & \multicolumn{2}{|c|}{ For Profit } & \multicolumn{2}{|c|}{ Not for Profit } & \multicolumn{2}{|c|}{ Public } \\
\hline & Coef & Marginal* & Coef & Marginal* & Coef & Marginal* \\
\hline \multicolumn{7}{|l|}{ Transitional } \\
\hline Asst obtaining social services & $\begin{array}{l}-0.105 \\
(0.833)\end{array}$ & $\begin{array}{c}-0.019 \\
(0.834)\end{array}$ & $\begin{array}{l}-0.550 \\
(0.169)\end{array}$ & $\begin{array}{l}-0.217 \\
(0.158)\end{array}$ & $\begin{array}{l}-0.286 \\
(0.615)\end{array}$ & $\begin{array}{l}-0.113 \\
(0.617)\end{array}$ \\
\hline Discharge planning & $\begin{array}{c}1.185 \\
(<0.001)\end{array}$ & $\begin{array}{c}0.407 \\
(<0.001)\end{array}$ & $\begin{array}{c}0.722 \\
(0.013)\end{array}$ & $\begin{array}{c}0.219 \\
(0.025)\end{array}$ & $\begin{array}{c}-0.697 \\
(0.055)\end{array}$ & $\begin{array}{l}-0.162 \\
(0.137)\end{array}$ \\
\hline Employment training & $\begin{array}{c}0.066 \\
(0.952)\end{array}$ & $\begin{array}{c}0.014 \\
(0.952)\end{array}$ & $\begin{array}{l}-0.702 \\
(0.052)\end{array}$ & $\begin{array}{c}-0.250 \\
(0.062)\end{array}$ & $\begin{array}{c}-1.023 \\
(0.020)\end{array}$ & $\begin{array}{l}-0.360 \\
(0.017)\end{array}$ \\
\hline Housing assistance & $\begin{array}{c}1.064 \\
(<0.001)\end{array}$ & $\begin{array}{c}0.137 \\
(0.017)\end{array}$ & $\begin{array}{l}-0.441 \\
(0.189)\end{array}$ & $\begin{array}{l}-0.138 \\
(0.211)\end{array}$ & $\begin{array}{l}-0.610 \\
(0.293)\end{array}$ & $\begin{array}{c}-0.186 \\
(0.311)\end{array}$ \\
\hline Referral to other trans srvcs & $\begin{array}{c}0.910 \\
(0.070)\end{array}$ & $\begin{array}{c}0.331 \\
(0.065)\end{array}$ & $\begin{array}{l}-0.055 \\
(0.846)\end{array}$ & $\begin{array}{l}-0.015 \\
(0.845)\end{array}$ & $\begin{array}{c}-1.75 \\
(<0.001)\end{array}$ & $\begin{array}{c}-0.562 \\
(<0.001)\end{array}$ \\
\hline \multicolumn{7}{|l|}{ Other services } \\
\hline Case management & $\begin{array}{c}0.754 \\
(0.129)\end{array}$ & $\begin{array}{c}0.293 \\
(0.111)\end{array}$ & $\begin{array}{c}0.249 \\
(0.502)\end{array}$ & $\begin{array}{c}0.093 \\
(0.507)\end{array}$ & $\begin{array}{c}-1.544 \\
(<0.001)\end{array}$ & $\begin{array}{c}-0.556 \\
(<0.001)\end{array}$ \\
\hline Child care & $\begin{array}{c}0.038 \\
(0.945)\end{array}$ & $\begin{array}{c}0.001 \\
(0.944)\end{array}$ & $\begin{array}{l}-0.137 \\
(0.711)\end{array}$ & $\begin{array}{l}-0.040 \\
(0.716)\end{array}$ & $\begin{array}{l}-1.604 \\
(<0.001)\end{array}$ & $\begin{array}{c}-0.469 \\
(<0.001)\end{array}$ \\
\hline Domestic violence & $\begin{array}{l}-0.506 \\
(0.227)\end{array}$ & $\begin{array}{l}-0.182 \\
(0.229)\end{array}$ & $\begin{array}{l}-0.054 \\
(0.886)\end{array}$ & $\begin{array}{c}-0.018 \\
(0.887)\end{array}$ & $\begin{array}{c}-0.770 \\
(0.502)\end{array}$ & $\begin{array}{l}-0.225 \\
(0.531)\end{array}$ \\
\hline HIV/AIDS education & $\begin{array}{c}0.125 \\
(0.876)\end{array}$ & $\begin{array}{c}0.045 \\
(0.878)\end{array}$ & $\begin{array}{l}-0.404 \\
(0.438)\end{array}$ & $\begin{array}{l}-0.153 \\
(0.425)\end{array}$ & $\begin{array}{l}-1.536 \\
(<0.001)\end{array}$ & $\begin{array}{c}-0.540 \\
(<0.001)\end{array}$ \\
\hline Outcome follow-up & $\begin{array}{c}-0.511 \\
(0.421)\end{array}$ & $\begin{array}{c}-0.193 \\
(0.419)\end{array}$ & $\begin{array}{l}-0.817 \\
(0.008)\end{array}$ & $\begin{array}{c}-0.313 \\
(0.004)\end{array}$ & $\begin{array}{c}-1.273 \\
(<0.001)\end{array}$ & $\begin{array}{c}-0.455 \\
(<0.001)\end{array}$ \\
\hline Transportation assist & $\begin{array}{c}1.234 \\
(<0.001)\end{array}$ & $\begin{array}{c}0.177 \\
(0.003)\end{array}$ & $\begin{array}{c}0.044 \\
(0.907)\end{array}$ & $\begin{array}{c}0.016 \\
(0.906)\end{array}$ & $\begin{array}{c}-0.184 \\
(0.864)\end{array}$ & $\begin{array}{c}-0.067 \\
(0.864)\end{array}$ \\
\hline Acupuncture & 0.186 & $\begin{array}{c}0.012 \\
(<0.001)\end{array}$ & $\begin{array}{l}-0.468 \\
(0.330)\end{array}$ & $\begin{array}{c}-0.050 \\
(0.441)\end{array}$ & $\begin{array}{c}1.600 \\
(<0.001)\end{array}$ & $\begin{array}{c}0.284 \\
(0.022)\end{array}$ \\
\hline
\end{tabular}

${ }^{\dagger}$ Boldface entries are statistically significant (p_value $\left.<0.100\right)$.

* Marginal effects measure the change in the probability that a given service is offered for a discrete change in MC from 0 to 1 . Marginal effects are calculated for a typical for-profit SAT facility comprising the following characteristics: primary focus is substance abuse, not affiliated with any type of hospital, not a solo practice, not a halfway house, no hospital inpatient services, no non-hospital residential services, offers outpatient services, methadone not dispensed, not accredited, licensed by the state, accepts cash or self-payment, accepts private insurance, does not accept Medicaid, does not accept Medicare, does not accept state-financed health insurance, does not receive public funds (not Medicaid or Medicare), offers payment assistance, and located in a metropolitan area in the Northeast. Marginal effects are calculated for typical not-for-profit and public SAT facilities comprising characteristics identical to for-profits except that they both accept Medicaid and receive public funds (not Medicaid or Medicare). 